Review

\title{
Current Status of the Spectrum and Therapeutics of Helicobacter pylori-Negative Mucosa-Associated Lymphoid Tissue Lymphoma
}

\author{
Sung-Hsin Kuo ${ }^{1,2,3}{ }^{D}$, Kun-Huei Yeh ${ }^{1,2,3}$, Chung-Wu Lin ${ }^{4}$, Jyh-Ming Liou ${ }^{5}$, Ming-Shiang Wu ${ }^{6}$, \\ Li-Tzong Chen $7,8,9$ and Ann-Lii Cheng 1,2,3,6,10,*(D)
}

check for updates

Citation: Kuo, S.-H.; Yeh, K.-H.; Lin, C.-W.; Liou, J.-M.; Wu, M.-S.; Chen, L.-T.; Cheng, A.-L. Current Status of the Spectrum and Therapeutics of Helicobacter pylori-Negative

Mucosa-Associated Lymphoid Tissue Lymphoma. Cancers 2022, 14, 1005. https://doi.org/10.3390/ cancers14041005

Academic Editor: Markus Raderer

Received: 18 January 2022

Accepted: 14 February 2022

Published: 16 February 2022

Publisher's Note: MDPI stays neutral with regard to jurisdictional claims in published maps and institutional affiliations.

Copyright: (C) 2022 by the authors. Licensee MDPI, Basel, Switzerland. This article is an open access article distributed under the terms and conditions of the Creative Commons Attribution (CC BY) license (https:// creativecommons.org/licenses/by/ $4.0 /)$.
1 Department of Oncology, National Taiwan University Hospital, National Taiwan University College of Medicine, Taipei 100, Taiwan; shkuo101@ntu.edu.tw (S.-H.K.); khyeh@ntu.edu.tw (K.-H.Y.)

2 Cancer Research Center, National Taiwan University College of Medicine, Taipei 100, Taiwan

3 Graduate Institute of Oncology, National Taiwan University College of Medicine, Taipei 100, Taiwan

4 Department of Pathology, National Taiwan University Hospital, National Taiwan University College of Medicine, Taipei 100, Taiwan; chungwulin@ntu.edu.tw

5 Department of Internal Medicine, National Taiwan University Cancer Center, National Taiwan University College of Medicine, Taipei 106, Taiwan; dtmed046@pchome.com.tw

6 Department of Internal Medicine, National Taiwan University Hospital, National Taiwan University College of Medicine, Taipei 100, Taiwan; mingshiang@ntu.edu.tw

7 National Institute of Cancer Research, National Health Research Institutes, Tainan 704, Taiwan; leochen@nhri.org.tw

8 Department of Internal Medicine, Kaohsiung Medical University Hospital, Kaohsiung Medical University, Kaohsiung 807, Taiwan

9 Department of Internal Medicine, National Cheng-Kung University Hospital, Tainan 704, Taiwan

10 Department of Oncology, National Taiwan University Cancer Center, National Taiwan University College of Medicine, Taipei 106, Taiwan

* Correspondence: alcheng@ntu.edu.tw; Tel.: +886-2-2312-3456 (ext. 67251); Fax: +886-2-2371-1174

Simple Summary: The prevalence of Helicobacter pylori (HP)-negative gastric mucosa-associated lymphoid tissue (MALT) lymphoma has increased over the last two decades, whereas that of HP-positive gastric MALT lymphoma has decreased. Although the role of first-line antibiotics in the treatment of HP-negative gastric MALT lymphomas remains ambiguous, several case series have reported that a first-line HP eradication therapy (HPE)-like regimen could result in complete remission in a proportion of patients with localized HP-negative gastric MALT lymphoma. Previous sporadic reports have indicated that certain patients with extragastric MALT lymphoma can respond to firstline antibiotic treatment as well. These findings suggest that, in contrast to antibiotic-unresponsive tumors, antibiotic-responsive tumors may be recognized within the spectrum of HP-negative MALT lymphoma. In addition to conventional chemotherapy and immunochemotherapy, macrolide antibiotics and immunomodulatory drugs have been previously used and demonstrated to be efficacious. This article provides the spectrum and therapeutics for HP-negative MALT lymphoma.

Abstract: Helicobacter pylori (HP)-unrelated mucosa-associated lymphoid tissue (MALT) lymphoma includes the majority of extragastric MALT lymphomas and a small proportion of gastric MALT lymphomas. Although the role of first-line antibiotics in treating HP-negative gastric MALT lymphomas remains controversial, HP eradication therapy (HPE)-like regimens may result in approximately 20-30\% complete remission (CR) for patients with localized HP-negative gastric MALT lymphoma. In these patients, $H$. heilmannii, H. bizzozeronii, and $H$. suis were detected in sporadic gastric biopsy specimens. Extragastric MALT lymphoma is conventionally treated with radiotherapy for localized disease and systemic chemotherapy for advanced and metastatic diseases. However, a proportion of extragastric MALT lymphomas, such as ocular adnexal lesions and small intestinal lesions, were reported to be controlled by antibiotics for Chlamydophila psittaci and Campylobacter jejuni, respectively. Some extragastric MALT lymphomas may even respond to first-line HPE. These findings suggest that some antibiotic-responsive tumors may exist in the family of HP-negative MALT lymphomas. Two mechanisms underlying the antibiotic responsiveness of HP-negative MALT lymphoma have 
been proposed. First, an HPE-like regimen may eradicate the antigens of unknown bacteria. Second, clarithromycin (the main component of HPE) may have direct or indirect antineoplastic effects, thus contributing to the CR of these tumors. For antibiotic-unresponsive HP-negative MALT lymphoma, high-dose macrolides and immunomodulatory drugs, such as thalidomide and lenalidomide, have reported sporadic success. Further investigation of new treatment regimens is warranted.

Keywords: MALT; Helicobacter pylori; negative; spectrum; bacteria; lymphomagenesis; macrolides; immunomodulatory drugs

\section{Introduction}

Isaacson and Wright first illustrated an entity of low-grade B-cell lymphoma in which most lymphoma cells were located in Peyer's patch-resembling structures and had a similar histomorphological appearance to mucosa-associated lymphoid tissue (MALT). This type of B-cell lymphoma was found in extranodal organs, such as the stomach, ocular adnexa, salivary glands, lungs, thyroid gland, and intestinal tract [1]. According to the Revised European-American Lymphoma classification system of the World Health Organization, this entity of MALT lymphoma is a distinct subgroup of indolent B-cell lymphomas and is renamed as the extranodal marginal zone lymphoma (MZL) of the MALT type [2,3]. Extranodal MZL or MALT lymphoma is the most common extranodal indolent B-cell lymphoma histologically characterized by diffuse small- and medium-sized lymphocytes (also called centrocyte-like cells), lymphoepithelial lesions, and partial plasma cell differentiation $[4,5]$. Among these extranodal MALT lymphomas, gastric MALT lymphomas are the most common, and are closely linked to Helicobacter pylori (HP) infection [5,6]. Several studies have demonstrated that first-line HP eradication therapy (HPE) can result in approximately 60-80\% complete remission (CR) of localized gastric MALT lymphoma [6-8]. However, approximately $20 \%$ of patients with gastric MALT lymphoma are initially diagnosed with HP-unrelated diseases, and thus have a lower CR rate in response to first-line HPE $[9,10]$. In addition to HP-negative gastric MALT lymphoma, extragastric MALT lymphomas have been described in various extranodal mucosal sites, including the conjunctiva, orbit, small intestine, large intestine, salivary gland, thyroid, skin, lung, breast, bladder, esophagus, and liver [10-12]. Extragastric MALT lymphomas are commonly characterized by HP-unrelated lymphoma [10-12].

In contrast to HP-positive gastric MALT lymphoma, the use of antibiotics as the first-line treatment for localized HP-negative gastric MALT lymphoma remains controversial $[13,14]$. However, some investigators have shown that approximately 20-30\% of patients with early-stage HP-negative gastric MALT lymphoma respond well to firstline HPE-like regimens $[9,10,15,16]$. Furthermore, studies have reported that some HPnegative Helicobacter spp., such as H. heilmannii, H. suis, and H. bizzozeronii, were detected in sporadic gastric biopsy samples of antibiotic-responsive HP-negative gastric MALT lymphoma $[17,18]$. In addition, increasing evidence demonstrates that Campylobacter jejuni and Chlamydia psittaci infections are closely linked to immunoproliferative small intestine disease (IPSID, small intestinal MALT lymphoma) and ocular adnexal MALT lymphoma (OAML), respectively $[10,12,19]$. Therefore, the administration of antibiotics to eradicate C. jejuni and C. psittaci cures a proportion of these patients $[10,12,19]$.

However, for extragastric MALT lymphomas that are not associated with bacterial infection, the use of radiotherapy (RT) as first-line treatment for localized disease and administration of systemic therapy, including chemotherapy or rituximab for advanced and metastatic diseases, remains the standard therapy $[10,20,21]$. Considering that the biological behaviors of localized HP-negative gastric MALT lymphoma and extragastric MALT lymphoma are relatively indolent, alternative treatments with less toxic strategies for treating these diseases have been explored [22-25]. Anecdotal case reports revealed that some patients with HP-negative extragastric MALT lymphomas might respond well to first-line 
HPE and are cured by antibiotic treatment [22]. These findings suggest that some antibioticresponsive extragastric MALT lymphomas may be recognized within the spectrum of antibiotic-responsive HP-negative MALT lymphoma. In addition to conventional systemic chemotherapy, high-dose clarithromycin, a macrolide, and an immunomodulatory agent, lenalidomide, have been reported to produce sporadic success for antibiotic-unresponsive or systemic treatment-refractory MALT lymphoma [24,25].

This article describes the treatment results of first-line antibiotics, including HPE regimens, in patients with localized HP-unrelated MALT lymphoma and the possible mechanisms of treatment success. Furthermore, we present the treatment efficacies and underlying antitumor biological machinery of high-dose macrolides, including clarithromycin and azithromycin, and immunomodulatory drugs, such as thalidomide and lenalidomide, in antibiotic-unresponsive, relapsed, and systemic treatment-refractory MALT lymphomas.

\section{Patients with HP-Negative Gastric MALT Lymphoma Who Respond Well to First-Line HPE}

In a systematic review of published data on the clinical symptoms and endoscopic manifestations of gastric lymphoma, including MALT lymphoma and diffuse large B-cell lymphoma (DLBCL) with and without MALT lymphoma, Zullo et al. reported that the HP infection status was negative in 117 (11.2\%) of 1146 cases of gastric lymphoma [26]. However, the widespread administration of the HPE regimen for patients with HP-positive gastritis or ulceration may prevent $\mathrm{HP}$-associated gastric diseases, such as gastric cancer, and may alter the prevalence of HP infection in patients with newly diagnosed gastric MALT lymphoma [27-29]. For example, Raderer et al. revealed that the HP-negative infection rates were $18 \%$ and $31.2 \%$ in patients with gastric MALT lymphoma diagnosed before and after 2014, respectively [30]. Mendes L et al. also showed that among gastric MALT lymphoma patients, the prevalence of HP-negative infection was significantly higher in patients diagnosed between 2005 and 2013 than in those diagnosed before 2005 (25/37 cases [67.6\%] vs. 24/61 cases [39.3\%]) [31]. Kuo et al. also reported that HP-negative infection was found in $29(31.5 \%)$ of 92 patients with gastric MALT lymphoma diagnosed between 2005 and 2014 [16].

Although earlier studies showed that most patients with HP-negative gastric MALT lymphoma lacked tumor remission after receiving antibiotic treatment [13,32,33], several case series reported that some patients with HP-negative MALT lymphoma were responsive to first-line HPE treatment $[9,10,15,16,30,34-36]$ (Table 1). In a pooled analysis of 110 patients obtained from 11 studies in which HP-negative status was confirmed by at least three negative HP examinations, Zullo et al. revealed a CR rate of $15.5 \%(17 / 110)$ for HP-negative gastric MALT lymphoma with HPE [15]. In contrast, Raderer et al. reported that the CR rate of first-line HPE for treating HP-negative gastric MALT lymphoma was $38.5 \%(5 / 13)$ [30]. In their study, most patients achieved CR within 9 months after HPE, except one patient who achieved partial remission (PR) at 23 months and subsequently achieved CR at 36 months after HPE (Table 1) [30]. Furthermore, three series with more than 15 patients with HP-negative gastric MALT lymphoma showed that first-line HPE resulted in CR rates of $29.4 \%$ (5/17) [37], 57.1\% (16/28, the median time to CR was 11.5 months [range 10.0 to 22.3]) [38], and 23.1\% (6/26, the median time to CR was 2 months [range 1-6]) [39], respectively (Table 1). Our findings revealed that among 25 patients with HPnegative gastric MALT lymphoma whose HP was negative for all histologic examination, rapid urease test, $\mathrm{C} 13$ breath test, and serology examination, eight patients (32\%) achieved CR, and the median time to CR was 7 months (range, 1-24 months) for these responders after first-line HPE (Table 1) [16]. 
Table 1. Published reports (more than 13 patients) on the efficacies of first-line antibiotics treatment in HP-negative gastric MALT lymphomas.

\begin{tabular}{|c|c|c|c|c|c|c|c|c|c|}
\hline Author & Country & $N$ & Stage & $\begin{array}{l}\text { CR Rate } \\
N(\%)\end{array}$ & $\begin{array}{c}\text { Median } \\
\text { Time to CR: } \\
\text { m (Range) }\end{array}$ & HP Test & HPE & $t(11 ; 18)$ & Ref. \\
\hline $\begin{array}{l}\text { Nakamura } \\
\text { T, et al. }\end{array}$ & Japan & 17 & $\begin{array}{l}\text { IE: } 16 \\
\text { IIE1: } 1\end{array}$ & $2(11.8)$ & ND & H, RUT, S & $\begin{array}{c}\mathrm{A}+\mathrm{C}+\mathrm{P} \\
\text { with/without } \\
\mathrm{M}\end{array}$ & $\begin{array}{l}\text { CR: 1/2(+) } \\
\text { Non-CR: } \\
7 / 15(+)\end{array}$ & {$[34]$} \\
\hline $\begin{array}{l}\text { Nakamura S, } \\
\text { et al. }\end{array}$ & Japan & 44 & ND & $6(13.6)$ & ND & $\begin{array}{c}\text { H, C, } \\
\text { RUT, } \\
\text { UBT, S }\end{array}$ & $\begin{array}{l}A+C+P \\
C+M+P \\
A+M+P\end{array}$ & NA & [35] \\
\hline $\begin{array}{l}\text { Stathis } \\
\text { et al. }\end{array}$ & Switzerland & 14 & $\begin{array}{l}\text { IE: } 9 \\
\text { IIE1: } 5\end{array}$ & $5(35.7)$ & ND & H, UBT, S & $\begin{array}{c}\mathrm{A}+\mathrm{C}+\mathrm{P}, \mathrm{C}+\mathrm{M}+ \\
\mathrm{P}, \text { or } \mathrm{A}+\mathrm{M}+\mathrm{P}\end{array}$ & NA & [36] \\
\hline $\begin{array}{l}\text { Asano } \\
\text { et al. }\end{array}$ & Japan & 17 & $\begin{array}{l}\text { IE: } 15 \\
\text { IIE: } 2\end{array}$ & $5(29.4)$ & ND & $\begin{array}{l}\text { H, RUT, } \\
\text { UBT, S }\end{array}$ & $\begin{array}{c}A+C+P(16 p t s) \\
\text { Or } \\
A+M+P(1 p t)\end{array}$ & $\begin{array}{c}\text { CR: 1/2(+), } \\
\text { Non-CR: } \\
6 / 9(+)\end{array}$ & [37] \\
\hline $\begin{array}{l}\text { Raderer } \\
\text { et al. }\end{array}$ & Austria & 13 & $\begin{array}{l}\text { IE: } 8 \\
\text { IIE1: } 5\end{array}$ & $5(38.5)$ & $3-36$ & H, UBT, S & $\begin{array}{c}C+M+P \text { or } C+ \\
A+P \\
(7 \text { or } 14 \mathrm{D})\end{array}$ & $\begin{array}{c}\text { CR: } 0 / 5(+), \\
\text { Non-CR: } 3 / 8(+)\end{array}$ & [30] \\
\hline $\begin{array}{l}\text { Gong } \\
\text { et al. }\end{array}$ & Korea & 28 & $\begin{array}{l}\text { IE: } 24 \\
\text { IIE: } 1 \\
\text { IV: } 3\end{array}$ & $16(57.1)$ & $\begin{array}{c}11.5 \\
(10.0-22.3)\end{array}$ & $\begin{array}{l}\text { H, RUT, } \\
\text { UBT, S }\end{array}$ & $\begin{array}{l}\mathrm{A}+\mathrm{C}+\mathrm{P} \\
7 \mathrm{D} \text { or } 14 \mathrm{D}\end{array}$ & NA & {$[38]$} \\
\hline Kuo et al. & Taiwan & 25 & $\begin{array}{l}\text { IE: } 22 \\
\text { IIE1: } 3\end{array}$ & $8(32.0)$ & $6.1(1-24)$ & $\begin{array}{l}\text { H, RUT, } \\
\text { UBT, S, C }\end{array}$ & $\begin{array}{c}\mathrm{A}+\mathrm{C}+\mathrm{P} \\
14 \mathrm{D}\end{array}$ & $\begin{array}{l}\text { CR: 0/7(+) } \\
\text { Non-CR: } \\
6 / 13(+)\end{array}$ & [16] \\
\hline $\begin{array}{l}\text { Strati } \\
\text { et al. }\end{array}$ & USA & 26 & IE: 26 & $6(23.1)$ & $2(1-6)$ & $\mathrm{H}, \mathrm{S}$ & $\begin{array}{c}\mathrm{A}+\mathrm{C}+\mathrm{P} \\
\text { or } \mathrm{M}+\mathrm{C}+\mathrm{P} ; 14 \mathrm{D}\end{array}$ & Non-CR: $0 / 3$ & [39] \\
\hline
\end{tabular}

Abbreviation: $N$, number; $\mathrm{CR}$, complete remission; $\mathrm{m}$, month; HP, Helicobacter pylori; HPE, HP eradication $\mathrm{t}(11 ; 18), \mathrm{t}(11 ; 18)(\mathrm{q} 21 ; \mathrm{q} 21)$; Ref, reference; ND, non-described; NA, non-analysis; pt, patient. HP examination test: $\mathrm{H}$, histology; RUT, rapid urease test; UBT, urea breath test; $\mathrm{S}$, serological test; C, culture; HPE regimen: A, amoxicillin; C, clarithromycin; M, metronidazole; $\mathrm{P}$, proton-pump inhibitor, including lansoprazole, pantoprazole or esomeprazole for 7 to 14 days (D).

The divergence between the low $\mathrm{CR}$ rate with antibiotics for HP-negative gastric MALT lymphoma in earlier studies [13-15,32-35] and the modest CR rate HPE in other results $[16,30,36-39]$ may be due to the insufficient time allowed lymphoma regression. It is known that some patients may achieve CR after 9 months of completing HPE, and some as late as 24 months $[16,30,38]$. Another reason is that $\mathrm{t}(11 ; 18)(\mathrm{q} 21 ; \mathrm{q} 21)$, a marker for antibiotic unresponsiveness [40,41], may be higher in series reporting a lower CR rate than those with a higher $\mathrm{CR}$ rate. We previously reported that $\mathrm{t}(11 ; 18)(\mathrm{q} 21 ; \mathrm{q} 21) / \mathrm{BIRC} 3-\mathrm{MALT} 1$ was found in 7 (43.8\%) of 16 patients with HP-negative gastric MALT lymphoma who did not respond to antibiotic treatment [16]. In a recent study of genetic alterations and somatic mutations in 57 patients with HP-negative gastric MALT lymphoma, Kiesewetter reported that 22 patients $(38.6 \%$ ) had MALT1 translocation (most $\mathrm{t}(11 ; 18)(\mathrm{q} 21 ; \mathrm{q} 21)$ /BIRC3MALT1), and 14 patients had mutations in NF-kB signaling molecules, such as TNFAIP3, CARD11, and MAP3K14 [42]. These findings may explain why none of the nine patients with HP-negative gastric MALT lymphoma who received first-line antibiotics achieved $\mathrm{CR}$ [42] because NF- $\mathrm{KB}$ signaling is often associated with antibiotic unresponsiveness in gastric MALT lymphoma [43-45].

\section{Non-Helicobacter pylori Helicobacter (NHPH) May Be Associated with Antibiotic-Responsiveness of HP-Negative Gastric MALT Lymphoma}

Although the reason for responsiveness to first-line HPE in 20\%-30\% of patients with HP-negative gastric MALT lymphoma remains uncertain, previous studies suggest that $\mathrm{NHPH}$, such as $H$. heilmannii, is linked to the development of gastric MALT lymphoma, although its prevalence is very low [17,46,47]. In a comparison of 202 patients with HPassociated gastritis and ulcers, and 202 patients with $H$. heilmannii-associated gastritis, Stolte et al. revealed that $H$. heilmannii was rarely associated with intestinal metaplasia and MALT when compared with HP bacteria [46]. Notably, among these 202 patients, 
seven had simultaneous gastric MALT lymphoma [46]. Furthermore, Morgner et al. reported that five patients with $H$. heilmannii-positive gastric MALT lymphoma confirmed through 16S ribosomal RNA amplification and sequencing methods achieved CR after receiving omeprazole and amoxicillin [17]. In a pathological review of gastric biopsies from 4074 patients, Okiyama et al. identified 11 patients with chronic gastritis, and four patients with gastric MALT lymphoma had H. heilmannii [47], which manifested as predominant straight appearances and large sizes in histological morphology, as previously described by Helimann and Borchard [48]. Among these four patients with $H$. heilmannii-positive gastric MALT lymphoma, two patients underwent antibiotic treatments, including lansoprazole, amoxicillin, and clarithromycin, and subsequently achieved CR [47]. These findings indicate that the HPE regimen can eradicate $H$. heilmannii, and thus cure patients with H. heilmannii-associated HP-negative gastric MALT lymphoma.

Nakamura et al. analyzed $236 \mathrm{HP}$-negative cases with gastric disease but without a history of HPE, in which the HP-negative status was confirmed by negative results in rapid urease test, histological examination, and polymerase chain reaction (PCR) for detecting HP [49]. They found that 49 cases were positive for $\mathrm{NHPH}$, including Helicobacter suis $(n=20), H$. heilmannii sensu stricto/H. ailurogastricus (Hhss/Ha) $(n=7)$, and non-Hhss/Ha $(n=22)$ [49]. Among 49 cases of NHPH, 11 were diagnosed with gastric MALT lymphoma (four with $H$. suis, two with Hhss/Ha, and five with non-Hhss/Ha) [49]. In a recent analysis of first-line HPE in 182 patients with gastric MALT lymphoma, Takigawa et al. showed that HP-negative patients had a higher prevalence rate of NHPH than HP-positive patients through Helicobacter sp.-specific PCR assay (16/29 [55\%] vs. $3 / 29$ [10\%], $p<0.05)$ [18]. Among 16 HP-negative NHPH-positive cases, five were positive for $H$. suis, eight for $H$. bizzozeronii, and three for both $H$. suis and $H$. bizzozeronii [18]. Furthermore, among patients with neither HP infection nor BIRC3-MALT1 fusion protein, positive NHPH cases had a higher CR rate than those with negative NHPH (12/16 [75\%] vs. 3/13 [23\%], $p=0.0092$ ) [18]. These findings suggest that NHPHs are linked with the development of certain HP-negative gastric MALT lymphomas, and eradication of NHPH by first-line HPE can eradicate this subtype of gastric MALT lymphoma. Further large studies to assess the prevalence of NHPH in patients diagnosed with HP-negative gastric MALT lymphoma are warranted.

Although most NHPHs are negative for the rapid urease test and ${ }^{13} \mathrm{C}$ urea breath test, several studies have shown that certain NHPHs were positive for urease test and contaminated with HP in HP-positive patients [50-52]. Goji et al. reported that a patient presenting with nodular gastritis at the antrum tested positive for rapid urease test and a ${ }^{13} \mathrm{C}$ urea breath test, but had negative results for stool antigen and serum anti-HP IgG antibody, and was further diagnosed with $H$. suis infection through PCR analysis of the 16S rRNA [50]. Goji et al. also reviewed the sensitivities of methods for detecting H. heilmannii-like organisms from 26 articles, and demonstrated that rapid urease test and immunohistochemical analysis were $40 \%$, whereas urea breath test, blood antibody analysis, and stool antigen analysis were $14.8 \%, 23.1 \%$, and $0 \%$, respectively [50]. Yakoob et al. assessed the prevalence of NHPH and HP in 250 patients with dyspepsia through PCR analyses of Helicobacter genus-specific $16 \mathrm{~S}$ rDNA, and reported that coinfection of $H$. heilmannii with HP was $6 \%$ in 17 patients, and the coinfection of $H$. felis with HP was $4 \%$ in 10 patients [51]. In the assessment of the prevalence of H. heilmannii sensu lato (H. heilmannii s.l.), a group of NHPH species [53], including $H$. suis, $H$. felis, H. bizzozeronii, $H$. heilmannii sensu stricto (s.s.), and $H$. salomonis in samples of rapid urease test positive gastric biopsy using $H$. heilmannii s.l.-specific PCR followed by nucleotide sequencing, Liu et al. showed that NHPH infection was found in 178 (11.9\%) of $1499 \mathrm{HP}$-positive patients [52]. Takigawa et al. also showed that $10 \%$ of patients with HP-positive MALT lymphoma had co-infection with NHPH, and NHPH-positive patients had more endoscopic nodular appearances in the gastric mucosa than NHPH-negative cases (3/16 [18.9\%] vs. 0/29 [0\%]) did [18]. These studies suggest that certain portions of NPHP may be involved in lymphomagenesis of urease test-positive patients, especially for patients with MALT lymphoma who presented with nodular appear- 
ances and negative serum antibody and stool antigen examination [18,50,54]. Although previous clinical studies exploring the efficacy of HPE in treating HP-positive gastric MALT lymphoma did not examine the prevalence of NHPH in these patients [6,7], further studies investigating the occurrence of NHPH in patients with MALT lymphoma presenting with nodular-like appearance irrespective of HP status are warranted.

\section{Efficacies of First-Line Antibiotics Treatment for Extragastric MALT Lymphoma}

Unlike localized gastric MALT lymphoma, which is mainly treated with first-line $\mathrm{HPE}$, the optimal management for localized extragastric MALT lymphoma has yet to be elucidated [10,12]. Conventionally, most patients with localized extragastric MALT lymphoma are treated with RT [20,55]. Considering the indolent biological behavior of localized extragastric MALT lymphoma, the use of less toxic strategies, such as "antibiotics," as a frontline treatment for this subtype of MALT lymphoma has been explored [19,20,22].

In addition to gastric MALT lymphoma, which is significantly associated with HP infection, increasing evidence demonstrates that C. jejuni, C. psittaci, and Borrelia burgdorferi are associated with IPSID, OAML, and cutaneous MALT lymphoma, respectively [56-60]. IPSID, an endemic disease, mainly occurs in the Mediterranean and sporadically in Western and Asian countries [10,20,56,61]. Patients with IPSID often present with chronic diarrhea complicated by malabsorption and weight loss, and are treated with first-line antibiotics, including tetracycline, metronidazole, ampicillin, and corticosteroids [61].

Ferreri et al. first reported an association between C. psittaci DNA in tumor samples and patients with OAML [57]. They demonstrated that using doxycycline to eradicate C. psittaci can cure a proportion of patients with OAML [57]. In a pooled analysis for the prevalence of C. psittaci DNA in patients with ocular lymphoma, Travaglino et al. revealed that C. psittaci was diverse in different countries, ranging from a low rate of $0 \%$ to $5 \%$ (Japan and Unities status) to a high rate of 33\% to 50\% (Austria, Italy, and Korea) [62]. In their analyses, the most common subtype of ocular adnexal B-cell lymphomas associated with C. psittaci infection was MALT lymphoma subtypes, with an odds ratio of 2.183 (95\% confidence interval, 1.092-4.360) [62]. In a systematic analysis of the efficacy of doxycycline in eradicating C. psittaci in 131 patients with OAML (from four retrospective studies and three prospective series), the authors demonstrated that first-line antibiotics resulted in a CR rate of $17.6 \%(n=23)$ and a partial remission $(P R)$ rate of $27.5 \%(n=36)[19,22,57,63]$. In an endemic area of Korea, Han et al. reported that among 90 patients with OAML who received one or two courses of first-line doxycycline (100 mg bid for 3 weeks each course), four patients achieved CR, 20 achieved PR, and 34 had stable disease [64]. Han et al. further found that the T1 stage was significantly associated with the overall response rate (ORR) when compared with T2 to T4 stages (37\% [21/57] vs. 10\% [3/28]), $p<0.001)$ [64]. Although most ORRs were observed in C. psittaci-positive patients, some OAML patients without C. psittaci infection had lymphoma regression after doxycycline treatments $[19,22,57,63]$. These findings suggest that doxycycline may eradicate non-C. psittaci microorganisms, and these doxycycline-sensitive unknown bacteria may be associated with the lymphomagenesis of OAML.

Patients with cutaneous MALT lymphoma often present with asymptomatic single papules, plaques, or nodules before diagnosis, and certain patients demonstrate serum antibody positivity for B. burgdorferi [60]. In endemic areas of Europe, the prevalence of B. burgdorferi was approximately $10 \%$ to $42 \%$ in patients with cutaneous MALT lymphoma through PCR analyses of B. burgdorferi DNA [59]. Based on the indolent course of most patients with cutaneous MALT lymphoma, the administration of first-line antibiotics using cephalosporins and tetracyclines is reasonable based on case reports demonstrating the antibiotic responsiveness of B. burgdorferi-positive cutaneous MALT lymphoma [59,60,65]. In a meta-analysis of 506 patients with primary cutaneous lymphoma obtained from 10 studies, Travaglino et al. showed that the prevalence of B. burgdorferi infection confirmed by PCR assay of B. burgdorferi DNA was significantly associated with B-cell lymphoma, 
including MALT lymphoma, and the positivity rate for B. burgdorferi in primary cutaneous MALT lymphoma was $8.3 \%$ [66].

Patients with pulmonary MALT lymphoma frequently present with an asymptomatic and indolent disease course, and most patients are diagnosed during an annual checkup [20,22,67]. Unlike the close association between bacterial infections and IPSID, OAML, and cutaneous MALT lymphoma, the association between Achromobacter xylosoxidans and pulmonary MALT lymphoma is controversial [68-70]. Adam et al. first reported that the prevalence of $A$. $x y l o s o x-$ idans was higher in tumor samples from patients with pulmonary MALT lymphoma than in lung tissues of control cases from six European countries (46.0\% (57/124) vs. 18.3\% (15/82), $p=0.004)$ through a specific nested PCR approach for the DNA of A. xylosoxidans [68]. Another study conducted by Borie et al. in France showed that sequences of $A$. xylosoxidans DNA were detected in four (30.8\%) of thirteen patients with MALT lymphoma and four $(40.0 \%)$ of ten healthy controls [69]. However, in the Japanese population, Aoyama et al. revealed that $A$. xylosoxidans DNA was only detected in one (1.9\%) of fifty-two patients with pulmonary MALT lymphomas [70]. Considering that pulmonary MALT lymphoma is relatively indolent and $A$. xylosoxidans is relatively resistant to antibiotic treatment, close observation of localized pulmonary MALT lymphoma has been suggested [71].

Unlike IPSID, OAML, cutaneous, and pulmonary MALT lymphomas that are reported to be associated with bacterial infection, few reports have shown an association between infectious bacteria and other extragastric MALT lymphomas. In a study of the relationship between $C$. psittaci DNA in blood samples and patients with salivary gland MALT lymphoma and Sjogren's syndrome, Fabris et al. showed that the detection rate for C. psittaci was higher in patients with MALT lymphoma $(6 / 18,33.3 \%)$ than in those without $(5 / 56$, $8.9 \%, p=0.012$ ) [72]. However, no reports have demonstrated the efficacy of doxycycline in the treatment of salivary gland MALT lymphoma.

However, anecdotal case series from the reviews of first-line antibiotics for extragastric MALT lymphoma by Kiesewetter et al. showed that two cases of salivary gland, one case of thyroid gland, and two cases of bladder MALT lymphoma achieved CR after receiving HPE and remained lymphoma-free after a median follow-up of 12 months (ranging from 5 to 48 months), in which gastric biopsy showed the presence of HP infection [22]. Won et al. reviewed the clinicopathological features and CR rates of 67 patients with colorectal MALT lymphoma who received differential first-line treatment, including surgery, chemotherapy, radiotherapy, and antibiotic treatment (including $\mathrm{HPE})$, Won et al. revealed that $12(80.0 \%)$ of 15 patients achieved CR after receiving antibiotic treatment, and 11 (91.7\%) of 12 patients had no recurrence after a long-term follow-up [73]. Moriya et al. also reported that a patient with esophageal MALT lymphoma achieved CR after HPE (positive anti-HP immunoglobulin $\mathrm{G}$ antibody in serum) and remained lymphoma-free, although HP infection in esophageal histological specimens was absent [74].

In addition to HP-negative gastric MALT lymphoma, some patients with extragastric MALT lymphoma may even respond to first-line HPE. These findings indicate that some antibiotic-responsive MALT lymphomas may exist in the family of HP-negative MALT lymphomas. However, the molecular mechanisms underlying these antibiotic-responsive HP-negative MALT lymphomas remain unclear.

\section{Possible Molecular Mechanisms of Antibiotic-Responsive HP-Negative MALT Lymphoma}

In addition to NHPH, other unknown bacterial sources can promote lymphomagenesis in HP-negative MALT lymphomas. Several hypotheses explain why certain patients with HP-negative MALT lymphoma respond to first-line HPE: (1) HPE regimens may eradicate NHPH, which is associated with the growth of HP-negative gastric MALT lymphoma in humans; (2) an HPE-like regimen may eradicate bacteria-associated antigens of unknown bacteria or unknown bacteria that may be associated with the lymphomagenesis of HP-negative MALT lymphoma; (3) clarithromycin, the principle component of the HPE 
regimen, may have direct or indirect antineoplastic effects, and thus cause CR of these tumors (Figure 1).

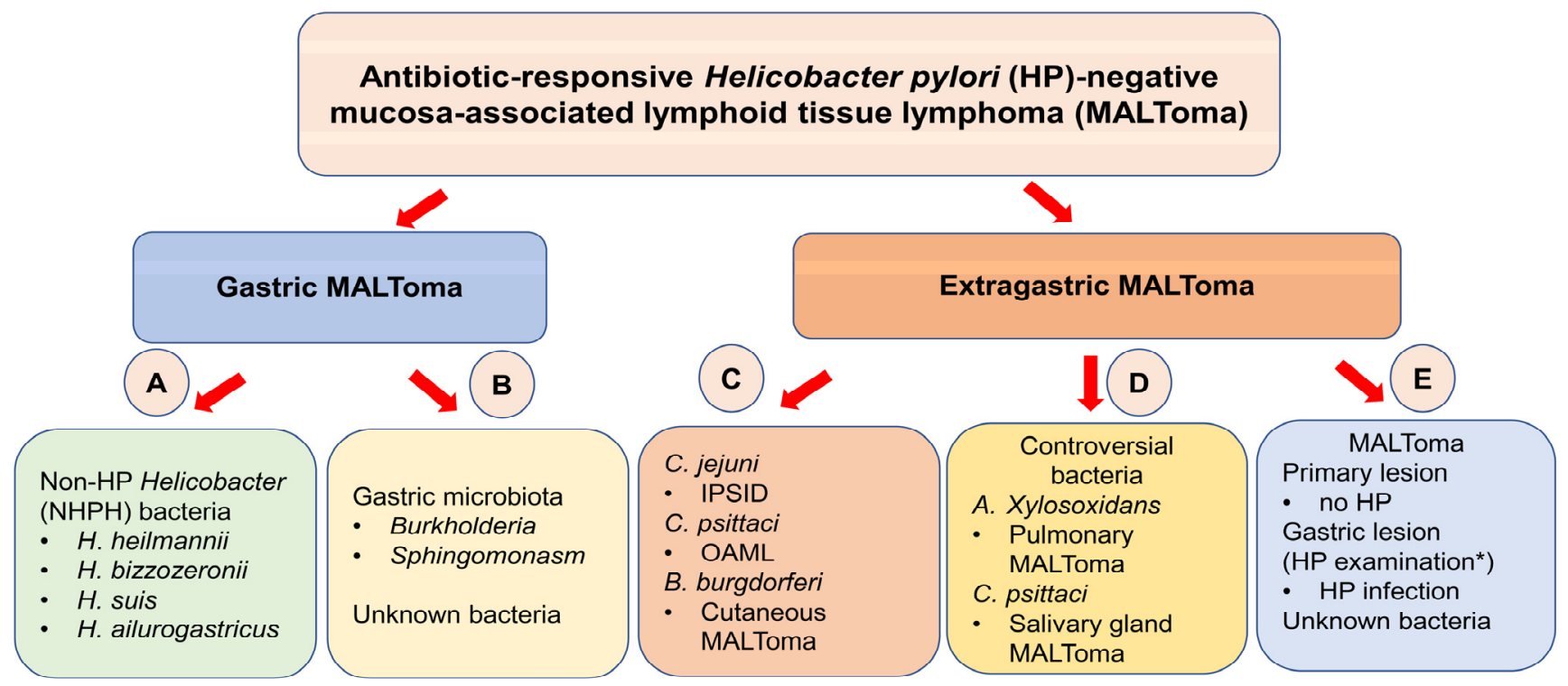

Figure 1. Schema of the spectrum of antibiotic-responsive Helicobacter pylori (HP)-negative mucosaassociated lymphoid tissue (MALT) lymphoma. (A) Among antibiotic-responsive HP-negative gastric MALT lymphoma, non-HP Helicobacter (NHPH) bacteria, such as H. heilmannii, H. bizzozeronii, $H$. suis, and H. ailurogastricus can be detected in sporadic cases. However, the precise mechanisms of $\mathrm{NHPH}$ on antibiotic-responsiveness remain unclear. (B) Gut microbiota, such as genera Burkholderia, Sphingomonasm, and unknown microbiota, may be involved in the lymphomagenesis of antibioticresponsive HP-negative gastric MALT lymphoma. (C) C. jejuni, C. psittaci, and B. burgdorferi are reported to be associated with the development of immune proliferative small intestinal diseases (IPSID), ocular adnexal MALT lymphoma (OAML), and cutaneous MALT lymphoma, and the use of doxycycline, tetracycline, metronidazole, doxycycline, or cephalosporin to eradicate the aforementioned bacteria, respectively, was found to be efficacious. (D) However, the association between A. xylosoxidans and the occurrence of pulmonary MALT lymphoma is controversial, as is the association between C. psittaci and the development of salivary gland MALT lymphoma. (E) Among sporadic cases that respond well to first-line HP eradication therapy (HPE), the presence of HP in the stomach but no direct evidence of HP in the primary lesion may explain the possibility that antigen stimuli or indirect T-specific lymphocytes or cytokines/chemokines homing to within the primary site from the lymphatic system of the stomach can be attenuated by the eradication of HP through HPE. * HP examination: histologic examination, rapid urease test, ${ }^{13} \mathrm{C}$ urea breath test, and serology examination.

Several lines of evidence have demonstrated that the indirect lymphomageneses of HP-positive gastric MALT lymphoma are mainly contributed by the communication with Bcells by tumor-infiltrating T cells and their stimulating T-helper (Th) cytokines, chemokines, costimulatory molecules, and regulatory T cells (Foxp3), or by micropathogenic antigenic stimulation or other unknown antigen stimuli [75-77]. These factors may explain why HPE may diminish the efficacy of B-cell growth from $\mathrm{T}$ cells and antigen stimuli by eliminating unknown bacteria. Another possible reason is that recruitment of HP-specific T-cells and antigens to tumor sites and their microenvironments from sites of HP-infected stomachs can be diminished through HPE [78], because some patients with extragastric MALT lymphoma who achieved CR after HPE had HP infection in the stomach, although HP could not be detected in tumor sites [22,74,79] (Figure 1).

For these antibiotic-responsive HP-negative MALT lymphomas, we cannot exclude the possibility that unknown bacteria, which HPE may eradicate, could participate in the formation of this tumor subtype. In the metagenomic analyses of microbiota obtained 
from the mucosal biopsy specimens of 33 patients with gastric MALT lymphoma (24 with naïve HP-negative status and 9 with previous HPE history) and 27 control patients without HP infection and cancer, Tanaka et al. demonstrated that the genera Burkholderia and Sphingomonas were more frequently found in patients with MALT lymphoma than in those of the control group [80]. These findings indicate that these microbes may be involved in the development of HP-negative MALT lymphomas. Burkholderia, a plant pathogen, has been reported to be an unscrupulous microbiota in immunocompromised patients [81]. Moreover, lectins from Burkholderia cenocepacia were found to interact and stimulate B cells to express N-linked glycan-containing B-cell antigen receptors in follicular cell lymphoma [82]. In assessing bismuth-containing HPE regimen in the treatment efficacies of HP and other gastric microbiota, Niu et al. revealed that the genera Rhodococcus, Lactobacillus, and Sphingomonas were more responsive to HPE [83]. These findings indicate that Sphingomonas may be linked with HP-negative gastric MALT lymphoma by modulating natural killer (NK) cell function and altering systemic immunity in in vivo mouse studies (Figure 1) [84]. Our previous study also demonstrated that increased infiltration of NK cells was associated with the lymphomagenesis of antibiotic-responsive gastric high-grade transformed MALT lymphoma (renamed as DLBCL with MALT) [85].

Clarithromycin, a macrolide antibiotic, is commonly used as the main component of the HPE regimen [6-8]. In addition to eradicating bacteria, clarithromycin has antineoplastic effects in B-cell lymphoma cells derived from BALB/c mice by downregulating anti-apoptotic molecules, BCL-2, and upregulating TNFR1 expression and its related molecules, such as caspases-3, -8 , and -9 [86]. Clarithromycin was also reported to enhance apoptotic effects on B-lymphocytes isolated from human peripheral blood by activating the FAS/FAS ligand pathway [87]. Additionally, it can enhance apoptotic effects on activated B-lymphocytes by downregulating Bcl-xL expression [88]. Furthermore, clarithromycin attenuated the activation of NF- $\kappa$ B stimulated by TNF- $\alpha$ in U-937 cells (human monocytes), Jurkat cells (T-cell lines), and peripheral blood mononuclear cells [89].

In addition to the direct anti-neoplastic effects of clarithromycin, several studies have demonstrated its immunomodulatory effects, including the activation of NK cells and CD8+ cells and costimulatory molecules, CD80, and alteration of cytokine production [90,91]. In vitro studies of dendritic cells derived from bone marrow progenitor cells showed that clarithromycin upregulated CD80 expression, inhibited IL-6 production, and attenuated IL-2 production in T cells co-cultured with dendritic cells [92]. Considering that IL-6 plays a crucial role in regulating and activating myeloid-derived suppressor cells (MDSCs) and that MDSCs can harbor anti-tumor immunity [93], it is speculated that clarithromycin may have immunomodulatory effects by decreasing IL-6 and subsequently suppressing MDSCs. Furthermore, in in vitro peripheral blood mononuclear cell studies, Ratzinger et al. revealed that azithromycin, another macrolide, and clarithromycin could repress the activity of CD4+ cells by hampering mTOR signaling [94], indicating that macrolides can act as immunomodulatory agents against cancer and lymphoma.

Further exploration of the precise mechanisms of lymphomagenesis for this spectrum of antibiotic-responsive HP-negative MALT lymphoma is warranted because a 2-week antibiotic regimen has fewer adverse effects than conventional radiotherapy or chemotherapy.

\section{Clinical Efficacy of Radiotherapy for HP-Negative MALT Lymphoma}

For localized and antibiotic-refractory HP-negative gastric MALT lymphoma, radiotherapy (RT) can provide local control but may induce acute and chronic adverse effects $[10,20,95,96]$. For example, patients with OAML who received RT had a high CR rate and promising event-free survival (EFS) but experienced side effects, such as cataracts, dry eyes, and keratitis [95,97]. However, several studies have demonstrated that reduction in RT (field or dose) not only provides promising therapeutic efficacies, but also has lower adverse effects for localized MALT lymphoma [96,98-101]. In a long-term follow-up of 290 patients with stage IE-IIE HP-independent (antibiotic-refractory or HP-negative) gastric MALT lymphoma who received different RT fields from three consecutive prospective 
trials of the German Study Group on Gastrointestinal Lymphoma (DSGL), Reinartz et al. revealed that reduced RT field (stage I, involved field [IF] RT with 40 Gy; stage IIE locoregional extended field [EF] RT with 30 Gy followed by boost RT) provided similar EFS and overall survival (OS) when compared with EF RT (stage I, EF or reduced EF; Stage II, EF-mediastinum or EF; $30 \mathrm{~Gy}$ followed by $10 \mathrm{~Gy}$ boost) [98]. Furthermore, reduced RT field caused less acute hematological toxicities, such as anemia, leukocytopenia, and thrombocytopenia, and gastrointestinal toxicities, such as nausea and diarrhea, and lower frequencies of late toxicities than EF RT [98]. In a retrospective analysis of 178 patients with HP-independent gastric MALT lymphoma, who were stage I (86\%) and HP-negative status (80\%), and of whom most received involved-site RT (ISRT) with 30 Gy in 15 fractions, Yahalom et al. showed that among 160 patients who received regular panendoscopic examinations, 152 (95\%) patients achieved CR, and in most patients acute toxicities were rare, except for two patients who developed grade 3 toxicities [99]. In addition to the reduced RT field, Pinnix et al. revealed that ISRT with 24 Gy $(n=11)$ provided similar local control, freedom from treatment failure, and OS when compared with those receiving ISRT with 30 Gy $(n=21)$ for treating HP-independent gastric MALT lymphoma [100]. In a prospective trial comparing two different IF RTs for stage IE-II1E HP-independent gastric MALT lymphoma, Schmelz et al. showed that RT with $25.2 \mathrm{~Gy}(n=10)$ produced a similar CR rate and gastrointestinal adverse effects when compared with RT with 36 Gy $(n=12)$ [101].

In the post-hoc analyses of a randomized, phase 3, non-inferiority trial comparing 24 Gy with 4 Gy for indolent lymphoma, including follicular lymphoma and MZL, authors reported that among 84 patients with MZL, patients $(n=41)$ receiving 24 Gy had a better 5 -year local progression-free survival (PFS) than those receiving 4 Gy $(n=43)(100 \%$ vs. $88 \%, p=0.015$ ) [96]. Taken together, these findings indicate that reduced field RT with at least 24 Gy could provide promising locoregional control and long-term survival and few adverse effects. However, Pinnix et al. reported that 2 Gy in 2 fractions (total 4 Gy) resulted in a CR of $86 \%$ and grade 1 eye syndrome in only $5 \%$ of 22 patients with ocular adnexal lymphoma (OAL, including fourteen with MALT lymphoma, five with follicular lymphoma, and two with mantle cell lymphoma) [102]. Cerrato et al. retrospectively analyzed 45 patients with MALT or MZL who were treated with 4 Gy in two 2-Gy fractions as curative or palliative intent, and revealed that low-dose RT (4 Gy) resulted in an ORR of 93\% (CR: 51\%, PR: 42\%) and a 2-year PFS and OS of 76\% and 91\%, respectively, without causing significant acute and late adverse effects [103]. Baron et al. also showed that among 36 patients with indolent OAL (20 patients with MALT lymphoma), low-dose RT (4 Gy) resulted in a similar ORR rate (100\% [CR: 50\%] vs. $87.5 \%$ [CR 58.3\%]) but fewer acute toxicities $(6 / 14$ [42.9\%] courses vs. 20/24 courses [83.3\%], $p=0.014)$ when compared with moderate-dose RT (21-36 Gy) [104]. Prospective studies to validate the local control rate and adverse effects of low-dose RT (4 Gy) in larger patients with MALT lymphoma are warranted.

\section{Clinical Efficacy of Immunomodulatory Agents for HP-Negative MALT Lymphoma}

Systemic therapy is often prescribed in localized patients who cannot tolerate the adverse effects of radiotherapy, or in those with advanced or disseminated MALT lymphoma $[10,20,21,23,105]$. Previously, several phase II studies evaluating new purine analogs of chemotherapy agents, such as fludarabine and $2 \mathrm{CdA}$, provided approximately $50 \%$ ORRs, but these drugs caused myelosuppression [10,20,21,23,105,106]. In a randomized International Extranodal Lymphoma Study Group (IELSG)-19 trial comparing chlorambucil, rituximab, and combined chlorambucil and rituximab as first-line treatments for patients with MALT lymphoma, Zucca et al. showed that the ORR for chlorambucil, rituximab, and combined chlorambucil and rituximab arms were $85.5 \%, 78.3 \%$, and $94.7 \%$, respectively [107]. The median PFS for chlorambucil, rituximab, and combined chlorambucil and rituximab arm was 8.3 years, 6.9 years, and not reached $(p=0.0119)$, respectively [107]. The 5-year OS was similar in the three arms (chlorambucil, 89\%; rituximab, 92\%; combined, 
90\%) [107]. In another phase II study evaluating the treatment response to rituximab and bendamustine (RB), Salar et al. revealed that RB resulted in an ORR of $100 \%$ (CR rate of 98\%) and a 7-year EFS of 87.7\% in 57 patients with HP-independent or relapsed gastric MALT lymphoma, or relapsed or refractory cutaneous MALT lymphoma [108]. Clinical studies have shown that ibrutinib (a Bruton tyrosine kinase inhibitor), a B-cell receptor signaling targeting agent, provides encouraging clinical outcomes in various indolent B-cell lymphomas, including MALT lymphoma $[109,110]$. In a phase II study exploring the single-agent ibrutinib in patients with relapsed/refractory marginal zone B-cell lymphoma (including nodal, extranodal, and splenic lesions), Noy et al. revealed that ibrutinib provided an ORR of $48 \%$ and a median PFS of 14.2 months in 60 patients, whereas $17 \%$ of patients discontinued ibrutinib because of its adverse effects [111].

Although rituximab-based chemotherapy provides a high CR rate and promising long-term survival for HP-negative MALT lymphoma [106-109], several studies have explored the efficacy of chemotherapy-free immunomodulatory agents, such as macrolides, thalidomide, and lenalidomide for these patients, as many have an indolent clinical course and rarely have comorbidities $[25,105,112]$. In an exploratory study evaluating the safety and efficacy of conventional clarithromycin (500 $\mathrm{mg}$ orally, twice daily for 6 months) among 13 patients with relapsed or refractory MALT lymphoma, Govi et al. revealed that clarithromycin resulted in an ORR of 38\% (CR, $n=2$; PR, $n=3)$ and a 3-year PFS of 58\% (Table 2) [113]. Based on these encouraging results, the same colleagues designed a phase II trial to assess the efficacy of high-dose clarithromycin (HD-K, clarithromycin $2 \mathrm{~g}$ daily, days 1-14, every 21 days, for four courses) [24]. They found that among 23 patients with relapsed or refractory MALT lymphoma, HD-K caused an ORR of $52 \%$ (CR, $n=6$; PR, $n=6$ ) and a 2-year PFS of $56 \%$ (Table 2) [24]. Ferreri et al. retrospectively analyzed patients with MALT lymphoma who received three different clarithromycin monotherapy regimens ( $1 \mathrm{~g} / \mathrm{d}$, for 6 months; $1 \mathrm{~g} / \mathrm{d}$ day 1-21, q35 day, for three courses; $2 \mathrm{~g} / \mathrm{d}$, days 1-14, q21 days, for four courses), and reported that the ORR and 3-year PFS for those with $1 \mathrm{~g} / \mathrm{d}$ were $57 \%$ and $60 \%$, respectively, and for those with $2 \mathrm{~g} / \mathrm{d}$ were $41 \%$ and $42 \%$, respectively [114]. Regarding the toxicities of clarithromycin, patients receiving $2 \mathrm{~g}$ of clarithromycin had more side effects, such as nausea, than those receiving $1 \mathrm{~g}$ of clarithromycin [114]. These findings indicate that a daily dose of $1 \mathrm{~g}$ of clarithromycin provides an optimal ORR and favorable clinical outcomes for patients with relapsed/refractory MALT lymphoma.

Azithromycin, a macrolide with a longer half-life than clarithromycin ( $68 \mathrm{~h}$ vs. $5 \mathrm{~h}$ ), was found to have a greater inhibitory effect on mTOR and CD4+ T cells than clarithromycin in an in vitro study [94,115]. Lagler et al. designed a phase II study to assess the efficacy of azithromycin (1.5 g once every week for 4 weeks) in patients with MALT lymphoma [116]. However, among 16 patients receiving azithromycin (2 with gastric and 14 with extragastric MALT lymphoma), two patients achieved CR, and two had PR (25\% ORR) [116]. Furthermore, Scheibenpflug et al. reported that among the 16 patients with MALT lymphoma, high intracellular concentrations of azithromycin in peripheral blood mononuclear cells were not associated with the responsiveness to azithromycin, but intracellular concentrations of azithromycin in polymorphonuclear leukocytes correlated with poor responsiveness [117].

The $\mathrm{t}(11 ; 18)(\mathrm{q} 21 ; \mathrm{q} 21)$ translocation, a trigger for NF- $\mathrm{kB}$ activation, was more frequently observed in cases of HP-negative MALT lymphoma than in those of HP-positive MALT lymphoma, and NF- $\mathrm{B}$ signaling contributes to the antibiotic unresponsiveness of gastric MALT lymphoma $[13,42,43,118,119]$. Our previous study also demonstrated that nuclear expression of NF-kB was significantly associated with the antibiotic-unresponsiveness of gastric MALT lymphoma [45,120,121]. Two important immunomodulatory drugs, or "IMiDs," thalidomide and lenalidomide, have been evaluated for efficacy in certain subgroups of hematological malignancies, including MALT lymphoma, since they have a targeting effect on NF-кB signaling [25,112,122,123]. Although a previous phase II study showed no ORR for thalidomide in the initial eight patients with antibiotic-unresponsive or disseminated MALT lymphoma (Table 2) [124], our previous study revealed that among ten patients with antibiotic-unresponsive or chemotherapy-refractory gastric MALT lym- 
phoma, thalidomide provided an ORR of $50 \%(\mathrm{CR}, n=2 ; \mathrm{PR}, n=3)$, and a 3 -year EFS of $38 \%$ (Table 2) [125].

Table 2. Summaries of the therapeutic efficacies of immunomodulatory drugs in relapsed or refractory MALT lymphoma.

\begin{tabular}{|c|c|c|c|c|c|c|c|c|c|}
\hline Authors & Drugs & Number & $\begin{array}{l}\text { Age } \\
\text { Median } \\
\text { (Range) }\end{array}$ & Lesions & $\begin{array}{l}\text { Previous } \\
\text { Treatment }\end{array}$ & ORR & $\begin{array}{c}\text { Most } \\
\text { Common } \\
\text { Side } \\
\text { Effects }\end{array}$ & PFS & Ref \\
\hline $\begin{array}{l}\text { Govi } \\
\text { et al. }\end{array}$ & $\begin{array}{l}\text { A regimen *: } \\
\text { Clarithromycin } \\
500 \mathrm{mg} \text { twice/D } \\
\text { for } 6 \mathrm{~m}\end{array}$ & $\stackrel{13}{M / F}=7 / 6$ & $57(36-80)$ & $\begin{array}{c}\text { Conjunctival/ } \\
\text { ocular+: } 11 \\
\text { Gastric: } 1 \\
\text { Breast: } 1\end{array}$ & $\begin{array}{l}\text { Relapsed } \\
\text { or } \\
\text { refractory }\end{array}$ & $\begin{array}{l}38.5 \% \\
\text { CR: } 2 \\
\text { PR: } 3\end{array}$ & Nausea & $\begin{array}{c}\text { 3-year } \\
58 \%\end{array}$ & [113] \\
\hline $\begin{array}{l}\text { Ferreri } \\
\text { et al. }\end{array}$ & $\begin{array}{l}\text { B regimen *: } \\
\text { Clarithromycin } \\
\text { 2g/D, D1-14 } \\
\text { every 21 D, } \\
4 \text { courses }\end{array}$ & $\stackrel{23}{M / F}=5 / 18$ & $70(47-88)$ & $\begin{array}{c}\text { Gastric: } 3 \\
\text { Extra-gastric } \\
\text { or } \\
\text { multiple: } 20\end{array}$ & $\begin{array}{l}\text { Relapsed } \\
\text { or } \\
\text { refractory }\end{array}$ & $\begin{array}{l}52.0 \% \\
\text { CR: } 6 \\
\text { PR: } 6\end{array}$ & Nausea & $\begin{array}{c}\text { 2-year } \\
56 \%\end{array}$ & [24] \\
\hline $\begin{array}{l}\text { Ferreri } \\
\text { et al. }\end{array}$ & $\begin{array}{l}\text { Clarithromycin } \\
1 \mathrm{~g}(\mathrm{~A} \text { regimen } * \text { or } \\
500 \mathrm{mg} \text { twice daily } \\
\mathrm{D} 1-21 \text {, every } 35 \mathrm{D} \\
\text { for } 3 \text { courses } \\
2 \mathrm{~g}\left(\mathrm{~B} \text { regimen }{ }^{*}\right)\end{array}$ & $\begin{array}{c}55 \\
\mathrm{M} / \mathrm{F}=31 / 24\end{array}$ & $65(30-88)$ & $\begin{array}{c}\text { Gastric: } 9 \\
\text { Extra-gastric: } \\
46 \\
\text { Stage I: } 40 \\
\text { Stage IV: } 15\end{array}$ & $\begin{array}{c}\text { Tx: naïve } \\
N=8 \\
\text { Previous } \\
\text { Tx: } N=47\end{array}$ & $\begin{array}{c}47.3 \% \\
\text { CR: } 13 \\
\text { PR: } 13 \\
1 \text { g vs. } 2 \text { g } \\
57 \% \text { vs. } \\
41 \% \\
p=0.28\end{array}$ & $\begin{array}{c}\text { Nausea } \\
1 \text { g vs. } 2 \mathrm{~g} \\
25 \% \text { vs. } \\
52 \% \\
p=0.03\end{array}$ & $\begin{array}{c}\text { 3-year } \\
52 \% \\
1 \text { g vs. } 2 \mathrm{~g} \\
78 \% \text { vs. } \\
41 \% \\
p=0.04\end{array}$ & [114] \\
\hline $\begin{array}{l}\text { Lagler } \\
\text { et al. }\end{array}$ & $\begin{array}{l}\text { Azithromycin } \\
1500 \text { mg once } \\
\text { Weekly } 4 \\
\text { time/per m } \\
3 \text { to } 6 \mathrm{~m}\end{array}$ & $\begin{array}{l}16 \\
M / F=6 / 10\end{array}$ & $68(47-88)$ & $\begin{array}{c}2 \text { Gastric } \\
14 \\
\text { Extra-gastric }\end{array}$ & $\begin{array}{l}\text { Tx: naïve } \\
N=12 \\
\text { Previous } \\
\text { Tx: } N=4\end{array}$ & $\begin{array}{l}25 \% \\
\text { CR: } 2 \\
\text { PR: } 2\end{array}$ & $\begin{array}{l}\text { Nausea } \\
\text { Diarrhea }\end{array}$ & $\begin{array}{l}\text { No } \\
\text { Report }\end{array}$ & [116] \\
\hline $\begin{array}{l}\text { Troch } \\
\text { et al. }\end{array}$ & $\begin{array}{l}\text { Thalidomide } \\
100 \text { mg D initially } \\
200 \text { mg after } \\
4 \text { weeks }\end{array}$ & $\stackrel{8}{M / F}=6 / 2$ & $60(36-73)$ & $\begin{array}{c}\text { Gastric: } 5 \\
\text { Extra-gastric: } \\
33\end{array}$ & $\begin{array}{l}\text { HPE, fail; } \\
\text { or } \\
\text { stage IV } \\
\text { disease }\end{array}$ & $\begin{array}{c}\text { Initial: } 0 \% \\
25.0 \% * * \\
\text { (after Tx) } \\
\text { CR, } 16.5 \mathrm{~m} \\
\text { CR, } 22.5 \mathrm{~m}\end{array}$ & Neuropathy & $\begin{array}{l}\text { No } \\
\text { Report }\end{array}$ & {$[124,126]$} \\
\hline $\begin{array}{l}\text { Kuo } \\
\text { et al. }\end{array}$ & $\begin{array}{c}\text { Thalidomide } \\
100 \mathrm{mg}-200 \mathrm{mg} \mathrm{D}, \\
\text { for } 6 \mathrm{~m}\end{array}$ & $\begin{array}{c}10 \\
M / F=6 / 2\end{array}$ & $62(48-78)$ & $\begin{array}{l}\text { Gastric: } 10 \\
\text { I/IIE1: } 3 \\
\text { IV: } 7\end{array}$ & $\begin{array}{l}\text { HPE or } \\
\text { C/T: failed }\end{array}$ & $\begin{array}{l}50.0 \% \\
\text { CR: } 2 \\
\text { PR: } 3\end{array}$ & Dizziness & $\begin{array}{c}\text { 3-year EFS; } \\
38 \%\end{array}$ & [125] \\
\hline $\begin{array}{l}\text { Kiese- } \\
\text { wetter } \\
\text { et al. }\end{array}$ & $\begin{array}{c}\text { Lenalidomide } \\
25 \text { mg/D D1-21, } \\
\text { every } 28 \text { D } \\
\text { Maximal: } 6 \text { cycles }\end{array}$ & $\mathrm{M} / \mathrm{F}=8 / 10$ & $60(41-79)$ & $\begin{array}{c}\text { Gastric: } 5 \\
\text { Extra-gastric: } \\
13\end{array}$ & $\begin{array}{l}\text { Previous tx: } \\
\quad 7 \\
\text { None: } 11\end{array}$ & $\begin{array}{l}\text { 61.1\% } \\
\text { CR: } 6 \\
\text { PR: } 5\end{array}$ & Pruritis & $\begin{array}{l}\text { Median } \\
\text { FU: } \\
20.3 \text { months } \\
\text { 17 pts: } \\
\text { alive }\end{array}$ & [127] \\
\hline $\begin{array}{l}\text { Kiese- } \\
\text { wetter } \\
\text { et al. }\end{array}$ & $\begin{array}{c}\text { Lenalidomide (Len) } \\
25 \text { mg D, D1-21, } \\
\text { every } 28 \mathrm{D} \\
\text { Maximal: } 6 \text { cycles } \\
\text { Rituximab (Rit) + } \\
\text { Len } \\
\text { Len: } 20 \mathrm{mg} \text { D } \\
\text { D1-21 } \\
\text { Rit: } 375 \mathrm{mg} / \mathrm{m}^{2} . \mathrm{D} 1 \\
\text { every } 28 \mathrm{D} \\
\text { Maximal: } 8 \text { cycles }\end{array}$ & $\begin{array}{c}\text { Len: } 16 \\
\mathrm{R}+\text { Len } \\
34 \\
\mathrm{M} / \mathrm{F}=19 / 31\end{array}$ & $67(33-85)$ & $\begin{array}{c}\text { Gastric: } 16 \\
\text { Extra-gastric: } \\
34 \\
\text { I-II: } 33 \\
\text { III-IV: } 17\end{array}$ & $\begin{array}{l}\text { Previous } \\
\text { Tx } \\
: 24\end{array}$ & $\begin{array}{l}72.0 \% \\
\text { CR: } 24 \\
\text { PR: } 12\end{array}$ & Pruritis & $\begin{array}{c}54 \% \\
\text { free-off } \\
\text { relapse } \\
\text { Median PFS: } \\
\text { 72.3 months } \\
\text { 5-year OS: } \\
92 \%\end{array}$ & [128] \\
\hline
\end{tabular}

Abbreviation: ORR, overall response rate; PFS, progression-free survival; Ref, reference; $\mathrm{D}$, daily; $\mathrm{m}$, months; $\mathrm{M}$ male; F, female; Tx, treatment; N, number; CR, complete remission; PR, partial remission; HPE, Helicobacter pylori eradication; EFS, event-free survival; FU, follow-up; OS, overall survival. *Clarithromycin regimen; ** $2(25 \%)$ of 8 patients with thalidomide achieved $\mathrm{CR}$ at $16.5 \mathrm{~m}$, and $22.5 \mathrm{~m}$ after starting treatment.

In a clinical phase II study assessing the efficacy of single-agent lenalidomide (25 mg daily days 1-21, every 28 days, each cycle) in treating 18 patients with MALT lymphoma (including five with HP-negative gastric and 13 with extragastric lesions), Kiesewetter et al. showed that lenalidomide resulted in an ORR of 61.1\% (six with CR and five with PR) [127]. In their study, 17 patients were alive without signs of lymphoma after a median follow-up of 20.3 months (Table 2) [127]. Kiesewetter et al. retrospectively analyzed 25 patients with MALT lymphoma (eighteen with lenalidomide and seven with thalidomide) and showed that seven $(28 \%)$ patients had delayed-onset responses with a median time to the best response of 7.3 months (range, 5.6-22.5 months) [126]. In an analysis of 50 patients with 
MALT lymphoma treated with lenalidomide-based regimens (lenalidomide monotherapy, $n=16$; lenalidomide plus rituximab, $n=34$ ), Kiesewetter et al. showed that lenalidomidebased regimens provided an ORR of $74 \%(54 \% \mathrm{CR})$, and estimated the median PFS and the 5-year OS rate to be 72 months and $92 \%$, respectively (Table 2) [128]. Interestingly, among these responders, three patients achieved CR between 12 and 32 months after starting the lenalidomide-based regimen, and one achieved PR from stable disease after 11 months [128]. The most important adverse effects of lenalidomide are mainly nonhematologic, including pruritus, nausea, fatigue, and headache [126-128]. Thus, for HPnegative MALT lymphoma, lenalidomide-based regimens can provide promising treatment efficacy and fewer hematological side effects. Physicians should allot sufficient time to observe delayed responses among patients without progression during follow-up after initiating lenalidomide treatment.

Based on the optimal response of single agents, clarithromycin or lenalidomide, the ongoing phase II study designed by the IELSG aims to explore the treatment efficacy and toxicity of combined clarithromycin and lenalidomide (lenalidomide [Revlimid] $20 \mathrm{mg}$ daily day 1-21 and clarithromycin $500 \mathrm{mg}$ twice daily day $1-28$, every 28 days for each course) for relapsed or refractory MALT lymphoma (ClinicalTrials.gov Identifier: NCT03031483). Previous studies have reported that low-dose cyclophosphamide has immunomodulatory effects and overcomes the resistance of lenalidomide in patients with multiple myeloma (MM) [129-132]. Considering the biological relationships between MM and MALT lymphoma (for example, plasma cell differentiation and serum immunoglobulin production) and immunological signaling pathways that contribute to the lymphomagenesis of MALT lymphoma [3,77,133-136], our ongoing prospective phase II trial (ClinicalTrials.gov Identifier: NCT04604028) aims to assess the ORR, toxicities, and time to progression of combined lenalidomide and low-dose cyclophosphamide (lenalidomide [Leavdo $\left.{ }^{\circledR}\right] 15 \mathrm{mg}$ daily, day 1-21; cyclophosphamide $50 \mathrm{mg}$ daily, day 1-21, each cycle every 28 days) for antibioticunresponsive and relapsed or refractory MALT lymphoma. Hopefully, these two ongoing trials will elucidate whether relapsed/refractory MALT lymphomas, including HP-negative MALT lymphoma, are responsive to lenalidomide-based combined immunomodulatory agent treatment.

\section{Conclusions}

In addition to HP-gastric MALT lymphoma, specific HP-negative gastric MALT lymphomas respond to first-line HPE. Considering that most patients with gastric MALT lymphoma present with localized disease and an indolent clinical course, the administration of HPE as first-line treatment for newly diagnosed gastric MALT lymphoma without lifethreatening emergencies is recommended, because HPE not only eradicates HP and NHPH, but also diminishes antigen stimuli or triggers an immune response against lymphoma cells. Although conventional therapy remains the standard treatment for HP-negative extragastric MALT lymphoma, subtypes of extragastric MALT lymphoma are responsive to specific antibiotics against $C$. jejuni, C. psittaci, and B. burgdorferi. Interestingly, sporadic reports indicate that certain patients with extragastric MALT lymphoma respond to firstline HPE. In contrast to antibiotic-unresponsive tumors, antibiotic-responsive tumors may be recognized within the spectrum of HP-negative MALT lymphomas. Further identification of unknown bacteria that participate in the lymphomagenesis, and exploration of the precise mechanisms and immune reactions of this spectrum of antibiotic-responsive HP-negative MALT lymphoma, are warranted. Based on the promising results and low toxicities of clarithromycin and lenalidomide for relapsed or refractory MALT lymphoma, further investigations of new chemotherapy-free treatment regimens with high efficacy and minimal adverse effects for antibiotic-unresponsive HP-negative MALT lymphoma are needed.

Author Contributions: S.-H.K. conceived, wrote and edited the paper. K.-H.Y., C.-W.L., J.-M.L., M.-S.W. and L.-T.C. contributed to review of the manuscript. A.-L.C. supervised the study. All authors have read and agreed to the published version of the manuscript. 
Funding: This research grant MOHW110-TDU-B-211-124002 was funded by Ministry of Health and Welfare, Taiwan.

Acknowledgments: This study was supported by research grants MOST 110-2811-B-002-576-, MOST 110-2314-B-002-278-, and MOST 110-2314-B-002-219-MY3 from the Ministry of Science and Technology, Taiwan; and NUTH 111-S0063 from National Taiwan University Hospital, Taiwan.

Conflicts of Interest: The authors declare no conflict of interest.

\section{References}

1. Isaacson, P.G.; Wright, D.H. Malignant lymphoma of mucosa-associated lymphoid tissue. A distinct type of B-cell lymphoma. Cancer 1983, 52, 1410-1416. [CrossRef]

2. Jaffe, E.S.; Harris, N.L.; Stein, H.; Vardiman, J.W. (Eds.) World Health Organization Classification of Tumours. In Pathology and Genetics of Tumours of Haematopoietic and Lymphoid Tissues; IARC Press: Lyon, France, 2001.

3. Isaacson, P.G.; Chott, A.; Nakamura, S.; Muller-Hermelink, H.K.; Harris, N.L.; Swerdlow, S.H. Extranodal marginal zone B-cell lymphoma of mucosa-associated lymphoid tissue (MALT lymphoma). In WHO Classification of Tumours of Haematopoietic and Lymphoid Tissues; Swerdlow, S.H., Campo, E., Harris, N.L., Jaffe, E.S., Pileri, S.A., Stein, H., Eds.; IARC: Lyon, France, 2008; pp. 214-217.

4. Isaacson, P.G. Mucosa-associated lymphoid tissue lymphoma. Semin. Hematol. 1999, 36, 139-147. [CrossRef] [PubMed]

5. Wotherspoon, A.C.; Dogan, A.; Du, M.-Q. Mucosa-associated lymphoid tissue lymphoma. Curr. Opin. Hematol. 2002,9 , 50-55. [PubMed]

6. Du, M.-Q.; Isaacson, P.G. Gastric MALT lymphoma: From aetiology to treatment. Lancet Oncol. 2002, 3, 97-104. [PubMed]

7. Zullo, A.; Hassan, C.; Cristofari, F.; Andriani, A.; De Francesco, V.; Ierardi, E.; Tomao, S.; Stolte, M.; Morini, S.; Vaira, D. Effects of Helicobacter pylori eradication on early stage gastric mucosa-associated lymphoid tissuelymphoma. Clin. Gastroenterol. Hepatol. 2010, 8, 105-110. [CrossRef] [PubMed]

8. Kuo, S.H.; Cheng, A.L. Helicobacter pylori and MALT: What's new? Hematol. Am. Soc. Hematol. Educ. Program. 2013, 109-117. [CrossRef]

9. Asano, N.; Iijima, K.; Koike, T.; Imatani, A.; Shimosegawa, T. Helicobacter pylori-negative gastric mucosa-associated lymphoid tissue lymphomas: A review. World J. Gastroenterol. 2015, 21, 8014-8020. [CrossRef] [PubMed]

10. Raderer, M.; Kiesewetter, B.; Ferreri, A.J.M. Clinicopathologic characteristics and treatment of marginal zone lymphoma of mucosa-associated lymphoid tissue (MALT lymphoma). CA Cancer J. Clin. 2016, 66, 152-171.

11. A clinical evaluation of the International Lymphoma Study Group classification of non-Hodgkin's lymphoma. The Non-Hodgkin's Lymphoma Classification Project. Blood 1997, 89, 3909-3918.

12. Zucca, E.; Conconi, A.; Pedrinis, E.; Cortelazzo, S.; Motta, T.; Gospodarowicz, M.K.; Patterson, B.J.; Ferreri, A.J.; Ponzoni, M.; Devizzi, L.; et al. Nongastric marginal zone B-cell lymphoma of mucosa-associated lymphoid tissue. Blood 2003, 101, 2489-2495. [PubMed]

13. Ye, H.; Liu, H.; Raderer, M.; Chott, A.; Ruskone-Fourmestraux, A.; Wotherspoon, A.; Dyer, M.J.; Chuang, S.S.; Dogan, A.; Isaacson, P.G.; et al. High incidence of $\mathrm{t}(11 ; 18)(\mathrm{q} 21 ; \mathrm{q} 21)$ in Helicobacter pylori-negative gastric MALT lymphoma. Blood 2003, 101, 2547-2550. [CrossRef]

14. Nakamura, S.; Matsumoto, T. Treatment strategy for gastric mucosa-associated lymphoid tissue lymphoma. Gastroenterol. Clin. N. Am. 2015, 44, 649-660.

15. Zullo, A.; Hassan, C.; Ridola, L.; De Francesco, V.; Rossi, L.; Tomao, S.; Vaira, D.; Genta, R.M. Eradication Therapy in Helicobacter pylori-negative, Gastric Low-grade Mucosa-associated Lymphoid Tissue Lymphoma Patients: A Systematic Review. J. Clin. Gastroenterol. 2013, 47, 824-827. [CrossRef] [PubMed]

16. Kuo, S.H.; Yeh, K.H.; Wu, M.S.; Lin, C.W.; Wei, M.F.; Liou, J.M.; Wang, H.P.; Chen, L.T.; Cheng, A.L. First-line antibiotic therapy in Helicobacter pylori-negative low-grade gastric mucosa-associated lymphoid tissue lymphoma. Sci. Rep. 2017, 7, 14333. [PubMed]

17. Morgner, A.; Lehn, N.; Andersen, L.P.; Thiede, C.; Bennedsen, M.; Trebesius, K.; Neubauer, B.; Neubauer, A.; Stolte, M.; Bayerdörffer, E. Helicobacter heilmannii-associated primary gastric low-grade MALT lymphoma: Complete remission after curing the infection. Gastroenterology 2000, 118, 821-828. [CrossRef]

18. Takigawa, H.; Yuge, R.; Masaki, S.; Otani, R.; Kadota, H.; Naito, T.; Hayashi, R.; Urabe, Y.; Oka, S.; Tanaka, S.; et al. Involvement of non-Helicobacter pylori helicobacter infections in Helicobacter pylori-negative gastric MALT lymphoma pathogenesis and efficacy of eradication therapy. Gastric Cancer 2021, 24, 937-945. [PubMed]

19. Zucca, E.; Bertoni, F.; Vannata, B.; Cavalli, F. Emerging role of infectious etiologies in the pathogenesis of marginal zone B-cell lymphomas. Clin. Cancer Res. 2014, 20, 5207-5216. [CrossRef] [PubMed]

20. Zucca, E.; Bertoni, F. The spectrum of MALT lymphoma at different sites: Biological and therapeutic relevance. Blood 2016, 127, 2082-2092. [PubMed]

21. Broccoli, A.; Zinzani, P.L. How do we sequence therapy for marginal zone lymphomas? Hematol. Am. Soc. Hematol. Educ. Program. 2020, 2020, 295-305.

22. Kiesewetter, B.; Raderer, M. Antibiotic therapy in nongastrointestinal MALT lymphoma: A review of the literature. Blood 2013, 122, 1350-1357. [PubMed] 
23. Raderer, M.; Kiesewetter, B. How I treat MALT lymphoma: 'A subjective interpretation of the gospel according to Isaacson .... .' ESMO Open 2020, 5, e000812. [PubMed]

24. Ferreri, A.J.; Sassone, M.; Kiesewetter, B.; Govi, S.; Scarfo, L.; Donadoni, G.; Raderer, M. High-dose clarithromycin is an active monotherapy for patients with relapsed/refractory extranodal marginal zone lymphoma of mucosa-associated lymphoid tissue (MALT): The HD-K phase II trial. Ann. Oncol. 2015, 26, 1760-1765. [PubMed]

25. Kiesewetter, B.; Simonitsch-Klupp, I.; Mayerhoefer, M.E.; Dolak, W.; Lukas, J.; Raderer, M. First Line Systemic Treatment for MALT Lymphoma-Do We Still Need Chemotherapy? Real World Data from the Medical University Vienna. Cancers 2020, $12,3533$. [CrossRef] [PubMed]

26. Zullo, A.; Hassan, C.; Andriani, A.; Cristofari, F.; Cardinale, V.; Spinelli, G.P.; Tomao, S.; Morini, S. Primary low-grade and high-grade gastric MALT-lymphoma presentation. J. Clin. Gastroenterol. 2010, 44, 340-344. [CrossRef] [PubMed]

27. Liou, J.M.; Lee, Y.C.; El-Omar, E.M.; Wu, M.S. Efficacy and Long-Term Safety of H. pylori Eradication for Gastric Cancer Prevention. Cancers 2019, 11, 593. [CrossRef] [PubMed]

28. Chang, J.S.; Kuo, S.H.; Chu, P.Y.; Shan, Y.S.; Tsai, C.R.; Tsai, H.J.; Chen, L.T. The Epidemiology of Gastric Cancers in the Era of Helicobacter pylori Eradication: A Nationwide Cancer Registry-Based Study in Taiwan. Cancer Epidemiol. Biomark. Prev. 2019, 28, 1694-1703. [CrossRef]

29. Chiang, T.H.; Chang, W.J.; Chen, S.L.; Yen, A.M.; Fann, J.C.; Chiu, S.Y.; Chen, Y.R.; Chuang, S.L.; Shieh, C.F.; Liu, C.Y.; et al. Mass eradication of Helicobacter pylori to reduce gastric cancer incidence and mortality: A long-term cohort study on Matsu Islands. Gut 2021, 70, 243-250.

30. Raderer, M.; Wöhrer, S.; Kiesewetter, B.; Dolak, W.; Lagler, H.; Wotherspoon, A.; Muellauer, L.; Chott, A. Antibiotic treatment as sole management of Helicobacter pylori-negative gastric MALT lymphoma: A single center experience with prolonged follow-up. Ann. Hematol. 2015, 94, 969-973. [CrossRef] [PubMed]

31. Sena Teixeira Mendes, L.; Attygalle, A.D.; Wotherspoon, A.C. Helicobacter pylori infection in gastric extranodal marginal zone lymphoma of mucosa-associated lymphoid tissue (MALT) lymphoma: A re-evaluation. Gut 2014, 63, 1526-1527. [CrossRef] [PubMed]

32. Ruskoné-Fourmestraux, A.; Lavergne, A.; Aegerter, P.H.; Megraud, F.; Palazzo, L.; de Mascarel, A.; Molina, T.; Rambaud, J.L. Predictive factors for regression of gastric MALT lymphoma after anti-Helicobacter pylori treatment. Gut 2001, 48, 297-303. [CrossRef] [PubMed]

33. Steinbach, G.; Ford, R.; Glober, G.; Sample, D.; Hagemeister, F.B.; Lynch, P.M.; McLaughlin, P.W.; Rodriguez, M.A.; Romaguera, J.E.; Sarris, A.H.; et al. Antibiotic treatment of gastric lymphoma of mucosa-associated lymphoid tissue. An uncontrolled trial. Ann. Intern. Med. 1999, 131, 88-95. [CrossRef]

34. Nakamura, T.; Seto, M.; Tajika, M.; Kawai, H.; Yokoi, T.; Yatabe, Y.; Nakamura, S. Clinical features and prognosis of gastric MALT lymphoma with special reference to responsiveness to H. pylori eradication and API2-MALT1 status. Am. J. Gastroenterol. 2008, 103, 62-70. [CrossRef] [PubMed]

35. Nakamura, S.; Sugiyama, T.; Matsumoto, T.; Iijima, K.; Ono, S.; Tajika, M.; Tari, A.; Kitadai, Y.; Matsumoto, H.; Nagaya, T.; et al. Long-term clinical outcome of gastric MALT lymphoma after eradication of Helicobacter pylori: A multicentre cohort follow-up study of 420 patients in Japan. Gut 2012, 61, 507-513. [CrossRef]

36. Stathis, A.; Chini, C.; Bertoni, F.; Proserpio, I.; Capella, C.; Mazzucchelli, L.; Pedrinis, E.; Cavalli, F.; Pinotti, G.; Zucca, E. Long-term outcome following Helicobacter pylori eradication in a retrospective study of 105 patients with localized gastric marginal zone B-cell lymphoma of MALT type. Ann. Oncol. 2009, 20, 1086-1093. [CrossRef] [PubMed]

37. Asano, N.; Iijima, K.; Terai, S.; Jin, X.; Ara, N.; Chiba, T.; Fushiya, J.; Koike, T.; Imatani, A.; Shimosegawa, T. Eradication therapy is effective for Helicobacter pylori-negative gastric mucosa-associated lymphoid tissue lymphoma. Tohoku J. Exp. Med. 2012, 228, 223-227. [CrossRef]

38. Gong, E.J.; Ahn, J.Y.; Jung, H.Y.; Park, H.; Ko, Y.B.; Na, H.K.; Jung, K.W.; Kim, D.H.; Lee, J.H.; Choi, K.D.; et al. Helicobacter pylori Eradication Therapy Is Effective as the Initial Treatment for Patients with H. pylori-Negative and Disseminated Gastric Mucosa-Associated Lymphoid Tissue Lymphoma. Gut Liver 2016, 10, 706-713. [CrossRef] [PubMed]

39. Strati, P.; Lee, S.T.; Teegavarupu, P.; Karri, A.; Anireddy, S.; Hagemeister, F.B.; Romaguera, J.; Fayad, L.E.; Rodriguez, M.A.; Samaniego, F.; et al. Frontline antibiotic therapy for early-stage Helicobacter pylori-negative gastric MALT lymphoma. Am. J. Hematol. 2019, 94, E150-E153. [CrossRef]

40. Liu, H.; Ye, H.; Dogan, A.; Ranaldi, R.; Hamoudi, R.A.; Bearzi, I.; Isaacson, P.G.; Du, M.-Q. T(11;18)(q21;q21) is associated with advanced mucosa-associated lymphoid tissue lymphoma that expresses nuclear BCL10. Blood 2001, 98, 1182-1187. [PubMed]

41. Liu, H.; Ye, H.; Ruskone-Fourmestraux, A.; De Jong, D.; Pileri, S.; Thiede, C.; Lavergne, A.; Boot, H.; Caletti, G.; Wündisch, T.; et al. $\mathrm{T}(11 ; 18)$ is a marker for all stage gastric MALT lymphomas that will not respond to H. pylori eradication. Gastroenterology 2002, 122, 1286-1294. [PubMed]

42. Kiesewetter, B.; Copie-Bergman, C.; Levy, M.; Wu, F.; Dupuis, J.; Barau, C.; Arcaini, L.; Paulli, M.; Lucioni, M.; Bonometti, A.; et al. Genetic Characterization and Clinical Features of Helicobacter pylori Negative Gastric Mucosa-Associated Lymphoid Tissue Lymphoma. Cancers 2021, 13, 2993. [CrossRef] [PubMed]

43. Du, M.-Q. MALT lymphoma: A paradigm of NF-kappaB dysregulation. Semin. Cancer Biol. 2016, 39, 49-60. 
44. Zhou, Y.; Ye, H.; Martin-Subero, J.I.; Hamoudi, R.; Lu, Y.J.; Wang, R.; Siebert, R.; Shipley, J.; Isaacson, P.G.; Dogan, A.; et al. Distinct comparative genomic hybridisation profiles in gastric mucosa-associated lymphoid tissue lymphomas with and without $\mathrm{t}(11 ; 18)(\mathrm{q} 21 ; \mathrm{q} 21)$. Br. J. Haematol. 2006, 133, 35-42. [PubMed]

45. Kuo, S.H.; Tsai, H.J.; Lin, C.W.; Yeh, K.H.; Lee, H.W.; Wei, M.F.; Shun, C.T.; Wu, M.S.; Hsu, P.N.; Chen, L.T.; et al. The B-cellactivating factor signalling pathway is associated with Helicobacter pylori independence in gastric mucosa-associated lymphoid tissue lymphoma without $\mathrm{t}(11 ; 18)(\mathrm{q} 21 ; \mathrm{q} 21)$. J. Pathol. 2017, 241, 420-433. [PubMed]

46. Stolte, M.; Kroher, G.; Meining, A.; Morgner, A.; Bayerdörffer, E.; Bethke, B. A comparison of Helicobacter pylori and H. heilmannii gastritis. A matched control study involving 404 patients. Scand. J. Gastroenterol 1997, 32, 28-33. [PubMed]

47. Okiyama, Y.; Matsuzawa, K.; Hidaka, E.; Sano, K.; Akamatsu, T.; Ota, H. Helicobacter heilmannii infection: Clinical, endoscopic and histopathological features in Japanese patients. Pathol. Int. 2005, 55, 398-404. [PubMed]

48. Heilmann, K.L.; Borchard, F. Gastritis due to spiral shaped bacteria other than Helicobacter pylori: Clinical, histological, and ultrastructural findings. Gut 1991, 32, 137-140. [CrossRef] [PubMed]

49. Nakamura, M.; Øverby, A.; Michimae, H.; Matsui, H.; Takahashi, S.; Mabe, K.; Shimoyama, T.; Sasaki, M.; Terao, S.; Kamada, T.; et al. PCR analysis and specific immunohistochemistry revealing a high prevalence of non-Helicobacter pylori Helicobacters in Helicobacter pylori-negative gastric disease patients in Japan: High susceptibility to an Hp eradication regimen. Helicobacter 2020, $25, \mathrm{e} 12700$.

50. Goji, S.; Tamura, Y.; Sasaki, M.; Nakamura, M.; Matsui, H.; Murayama, S.Y.; Ebi, M.; Ogasawara, N.; Funaki, Y.; Kasugai, K. Helicobacter suis-Infected Nodular Gastritis and a Review of Diagnostic Sensitivity for Helicobacter heilmannii-Like Organisms. Case Rep. Gastroenterol. 2015, 9, 179-187. [CrossRef] [PubMed]

51. Yakoob, J.; Abbas, Z.; Khan, R.; Naz, S.; Ahmad, Z.; Islam, M.; Awan, S.; Jafri, F.; Jafri, W. Prevalence of non Helicobacter pylori species in patients presenting with dyspepsia. BMC Gastroenterol. 2012, 12, 3.

52. Liu, J.; He, L.; Haesebrouck, F.; Gong, Y.; Flahou, B.; Cao, Q.; Zhang, J. Prevalence of Coinfection with Gastric Non-Helicobacter pylori Helicobacter (NHPH) Species in Helicobacter pylori-infected Patients Suffering from Gastric Disease in Beijing, China. Helicobacter 2015, 20, 284-290. [PubMed]

53. Bento-Miranda, M.; Figueiredo, C. Helicobacter heilmannii sensu lato: An overview of the infection in humans. World J. Gastroenterol. 2014, 20, 17779-17787. [CrossRef] [PubMed]

54. Takigawa, H.; Masaki, S.; Naito, T.; Yuge, R.; Urabe, Y.; Tanaka, S.; Sentani, K.; Matsuo, T.; Matsuo, K.; Chayama, K.; et al. Helicobacter suis infection is associated with nodular gastritis-like appearance of gastric mucosa-associated lymphoid tissue lymphoma. Cancer Med. 2019, 8, 4370-4379. [CrossRef] [PubMed]

55. Yahalom, J. Patients with H pylori-independent MALT lymphoma are curable with radiotherapy. Oncology 2011, 25, 1147-1149. [PubMed]

56. Lecuit, M.; Abachin, E.; Martin, A.; Poyart, C.; Pochart, P.; Suarez, F.; Bengoufa, D.; Feuillard, J.; Lavergne, A.; Gordon, J.I.; et al. Immunoproliferative small intestinal disease associated with Campylobacter jejuni. N. Engl. J. Med. 2004, 350, 239-248. [CrossRef] [PubMed]

57. Ferreri, A.J.; Guidoboni, M.; Ponzoni, M.; De Conciliis, C.; Dell’Oro, S.; Fleischhauer, K.; Caggiari, L.; Lettini, A.A.; Dal Cin, E.; Ieri, R.; et al. Evidence for an association between Chlamydia psittaci and ocular adnexal lymphomas. J. Natl. Cancer Inst. 2004, 96, 586-594. [PubMed]

58. Roggero, E.; Zucca, E.; Mainetti, C.; Bertoni, F.; Valsangiacomo, C.; Pedrinis, E.; Borisch, B.; Piffaretti, J.C.; Cavalli, F.; Isaacson, P.G. Eradication of Borrelia burgdorferi infection in primary marginal zone B-cell lymphoma of the skin. Hum. Pathol. 2000, 31, 263-268. [PubMed]

59. Ferreri, A.J.; Govi, S.; Ponzoni, M. Marginal zone lymphomas and infectious agents. Semin. Cancer Biol. 2013, 23, 431-440. [PubMed]

60. Biernat, M.M.; Wróbel, T. Bacterial Infection and Non-Hodgkin B-Cell Lymphoma: Interactions between Pathogen, Host and the Tumor Environment. Int. J. Mol. Sci. 2021, 22, 7372. [PubMed]

61. Evangelista-Leite, D.; Madaloso, B.A.; Yamashita, B.S.; Aloise, F.E.; Verdasca, L.P.; de Mello, M.L.; Hayashi, R.M.; Chehter, E.Z. Treating chronic diarrhea: A systematic review on Immunoproliferative Small Intestinal Disease (IPSID). PLoS ONE 2021, 16, e0253695.

62. Travaglino, A.; Pace, M.; Varricchio, S.; Pepa, R.D.; Iuliano, A.; Picardi, M.; Pane, F.; Staibano, S.; Mascolo, M. Prevalence of Chlamydia psittaci, Chlamydia pneumoniae, and Chlamydia trachomatis Determined by Molecular Testing in Ocular Adnexa Lymphoma Specimens. Am. J. Clin. Pathol. 2020, 153, 427-434. [PubMed]

63. Ferreri, A.J.; Ponzoni, M.; Guidoboni, M.; De Conciliis, C.; Resti, A.G.; Mazzi, B.; Lettini, A.A.; Demeter, J.; Dell'Oro, S.; Doglioni, C.; et al. Regression of ocular adnexal lymphoma after Chlamydia psittaci-eradicating antibiotic therapy. J. Clin. Oncol. 2005, 23, 5067-5073. [CrossRef] [PubMed]

64. Han, J.J.; Kim, T.M.; Jeon, Y.K.; Kim, M.K.; Khwarg, S.I.; Kim, C.W.; Kim, I.H.; Heo, D.S. Long-term outcomes of first-line treatment with doxycycline in patients with previously untreated ocular adnexal marginal zone B cell lymphoma. Ann. Hematol. 2015, 94, 575-581. [CrossRef] [PubMed]

65. Perrone, S.; D’Elia, G.M.; Annechini, G.; Pulsoni, A. Infectious Aetiology of Marginal Zone Lymphoma and Role of Anti-infective Therapy. Mediterr. J. Hematol. Infect. Dis. 2016, 8, e2016006. [CrossRef] [PubMed] 
66. Travaglino, A.; Varricchio, S.; Pace, M.; Russo, D.; Picardi, M.; Baldo, A.; Staibano, S.; Mascolo, M. Borrelia burgdorferi in primary cutaneous lymphomas: A systematic review and meta-analysis. J. Dtsch. Dermatol. Ges. 2020, 18, 1379-1384. [CrossRef]

67. Sammassimo, S.; Pruneri, G.; Andreola, G.; Montoro, J.; Steffanoni, S.; Nowakowski, G.S.; Gandini, S.; Negri, M.; Habermann, T.M.; Raderer, M.; et al. A retrospective international study on primary extranodal marginal zone lymphoma of the lung (BALT lymphoma) on behalf of International Extranodal Lymphoma Study Group (IELSG). Hematol. Oncol. 2016, 34, 177-183. [CrossRef]

68. Adam, P.; Czapiewski, P.; Colak, S.; Kosmidis, P.; Tousseyn, T.; Sagaert, X.; Boudova, L.; Okoń, K.; Morresi-Hauf, A.; Agostinelli, C.; et al. Prevalence of Achromobacter xylosoxidans in pulmonary mucosa-associated lymphoid tissue lymphoma in different regions of Europe. Br. J. Haematol. 2014, 164, 804-810. [CrossRef] [PubMed]

69. Borie, R.; Caro, V.; Nunes, H.; Kambouchner, M.; Cazes, A.; Antoine, M.; Crestani, B.; Leroy, K.; Copie-Bergman, C.; Kwasiborski, A.; et al. No evidence for a pathogen associated with pulmonary MALT lymphoma: A metagenomics investigation. Infect. Agent Cancer 2021, 16, 10. [CrossRef] [PubMed]

70. Aoyama, S.; Masaki, A.; Sakamoto, Y.; Takino, H.; Murase, T.; Ohshima, K.; Yoshino, T.; Kato, S.; Inagaki, H. Achromobacter Infection Is Rare in Japanese Patients with Pulmonary B-cell Lymphoma. Intern. Med. 2018, 57, 789-794. [CrossRef] [PubMed]

71. Sanguedolce, F.; Zanelli, M.; Zizzo, M.; Bisagni, A.; Soriano, A.; Cocco, G.; Palicelli, A.; Santandrea, G.; Caprera, C.; Corsi, M.; et al. Primary Pulmonary B-Cell Lymphoma: A Review and Update. Cancers 2021, 13, 415. [PubMed]

72. Fabris, M.; Dolcetti, R.; Pasini, E.; Quartuccio, L.; Pontarini, E.; Salvin, S.; Ponzoni, M.; Scott, C.A.; De Vita, S. High prevalence of Chlamydophila psittaci subclinical infection in Italian patients with Sjögren's syndrome and parotid gland marginal zone B-cell lymphoma of MALT-type. Clin. Exp. Rheumatol. 2014, 32, 61-65.

73. Won, J.H.; Kim, S.M.; Kim, J.W.; Park, J.H.; Kim, J.Y. Clinical features, treatment and outcomes of colorectal mucosa-associated lymphoid tissue (MALT) lymphoma: Literature reviews published in English between 1993 and 2017. Cancer Manag. Res. 2019, 11, 8577-8587. [CrossRef] [PubMed]

74. Moriya, K.; Tamura, H.; Nakamura, K.; Hosone, M.; Inokuchi, K. A primary esophageal MALT lymphoma patient with Helicobacter pylori infection achieved complete remission after H. pylori eradication without anti-lymphoma treatment. Leuk. Res. Rep. 2016, 7, 2-5. [CrossRef] [PubMed]

75. Craig, V.J.; Arnold, I.; Gerke, C.; Huynh, M.Q.; Wundisch, T.; Neubauer, A.; Renner, C.; Falkow, S.; Müller, A. Gastric MALT lymphoma B cells express polyreactive, somatically mutated immunoglobulins. Blood 2010, 115, 581-591.

76. Kuper-Hommel, M.J.; van Krieken, J.H. Molecular pathogenesis and histologic and clinical features of extranodal marginal zone lymphomas of mucosa-associated lymphoid tissue type. Leuk. Lymphoma 2012, 53, 1032-1045. [PubMed]

77. Kuo, S.H.; Wu, M.S.; Yeh, K.H.; Lin, C.W.; Hsu, P.N.; Chen, L.T.; Cheng, A.L. Novel Insights of Lymphomagenesis of Helicobacter pylori-Dependent Gastric Mucosa-Associated Lymphoid Tissue Lymphoma. Cancers 2019, 11, 547.

78. Sakai, Y.; Kobayashi, M. Lymphocyte 'homing' and chronic inflammation. Pathol. Int. 2015, 65, 344-354.

79. Kuo, S.H.; Yao, M.; Tasi, C.H.; Lin, C.W.; Liou, J.M.; Ma, W.L.; Cheng, A.L. A prospective study of first-line Helicobacter pylori eradication therapy in treating localized extragastric mucosa-associated lymphoid tissue lymphoma. Ann. Oncol. 2018, 29 (Suppl. 8), viii359-viii371. [CrossRef]

80. Tanaka, T.; Matsuno, Y.; Torisu, T.; Shibata, H.; Hirano, A.; Umeno, J.; Kawasaki, K.; Fujioka, S.; Fuyuno, Y.; Moriyama, T.; et al. Gastric microbiota in patients with Helicobacter pylori-negative gastric MALT lymphoma. Medicine 2021, 100, e27287. [CrossRef]

81. Segonds, C.; Clavel-Batut, P.; Thouverez, M.; Grenet, D.; Le Coustumier, A.; Plésiat, P.; Chabanon, G. Microbiological and epidemiological features of clinical respiratory isolates of Burkholderia gladioli. J. Clin. Microbiol. 2009, 47, 1510-1516. [CrossRef] [PubMed]

82. Schneider, D.; Dühren-von Minden, M.; Alkhatib, A.; Setz, C.; van Bergen, C.A.; Benkißer-Petersen, M.; Wilhelm, I.; Villringer, S.; Krysov, S.; Packham, G.; et al. Lectins from opportunistic bacteria interact with acquired variable-region glycans of surface immunoglobulin in follicular lymphoma. Blood 2015, 125, 3287-3296. [CrossRef] [PubMed]

83. Niu, Z.Y.; Li, S.Z.; Shi, Y.Y.; Xue, Y. Effect of gastric microbiota on quadruple Helicobacter pylori eradication therapy containing bismuth. World J. Gastroenterol. 2021, 27, 3913-3924. [CrossRef]

84. Wingender, G.; Stepniak, D.; Krebs, P.; Lin, L.; McBride, S.; Wei, B.; Braun, J.; Mazmanian, S.K.; Kronenberg, M. Intestinal microbes affect phenotypes and functions of invariant natural killer T cells in mice. Gastroenterology 2012, 143, 418-428. [PubMed]

85. Kuo, S.H.; Chen, L.T.; Chen, C.L.; Doong, S.L.; Yeh, K.H.; Wu, M.S.; Mao, T.L.; Hsu, H.C.; Wang, H.P.; Lin, J.T.; et al. Expression of CD86 and increased infiltration of NK cells are associated with Helicobacter pylori-dependent state of early stage high-grade gastric MALT lymphoma. World J. Gastroenterol. 2005, 11, 4357-4362. [CrossRef] [PubMed]

86. Ohara, T.; Morishita, T.; Suzuki, H.; Masaoka, T.; Ishii, H.; Hibi, T. Antibiotics directly induce apoptosis in B cell lymphoma cells derived from BALB/c mice. Anticancer Res. 2004, 24, 3723-3730. [PubMed]

87. Ishimatsu, Y.; Kadota, J.; Iwashita, T.; Nagata, T.; Ishii, H.; Shikuwa, C.; Kaida, H.; Mukae, H.; Kohno, S. Macrolide antibiotics induce apoptosis of human peripheral lymphocytes in vitro. Int. J. Antimicrob. Agents 2004, 24, 247-253. [CrossRef] [PubMed]

88. Mizunoe, S.; Kadota, J.; Tokimatsu, I.; Kishi, K.; Nagai, H.; Nasu, M. Clarithromycin and azithromycin induce apoptosis of activated lymphocytes via down-regulation of Bcl-xL. Int. Immunopharmacol. 2004, 4, 1201-1207. [CrossRef] [PubMed]

89. Ichiyama, T.; Nishikawa, M.; Yoshitomi, T.; Hasegawa, S.; Matsubara, T.; Hayashi, T.; Furukawa, S. Clarithromycin inhibits NF-kappaB activation in human peripheral blood mononuclear cells and pulmonary epithelial cells. Antimicrob. Agents Chemother. 2001, 45, 44-47. [CrossRef] [PubMed] 
90. Van Nuffel, A.M.; Sukhatme, V.; Pantziarka, P.; Meheus, L.; Sukhatme, V.P.; Bouche, G. Repurposing Drugs in Oncology (ReDO)-clarithromycin as an anti-cancer agent. Ecancermedicalscience 2015, 9, 513. [CrossRef] [PubMed]

91. Kanoh, S.; Rubin, B.K. Mechanisms of Action and Clinical Application of Macrolides as Immunomodulatory Medications. Clin. Microbiol. Rev. 2010, 23, 590-615.

92. Sugiyama, K.; Shirai, R.; Mukae, H.; Ishimoto, H.; Nagata, T.; Sakamoto, N.; Ishii, H.; Nakayama, S.; Yanagihara, K.; Mizuta, Y.; et al. Differing effects of clarithromycin and azithromycin on cytokine production by murine dendritic cells. Clin. Exp. Immunol. 2007, 147, 540-546. [PubMed]

93. Weber, R.; Groth, C.; Lasser, S.; Arkhypov, I.; Petrova, V.; Altevogt, P.; Utikal, J.; Umansky, V. IL-6 as a major regulator of MDSC activity and possible target for cancer immunotherapy. Cell Immunol. 2021, 359, 104254. [PubMed]

94. Ratzinger, F.; Haslacher, H.; Poeppl, W.; Hoermann, G.; Kovarik, J.J.; Jutz, S.; Steinberger, P.; Burgmann, H.; Pickl, W.F.; Schmetterer, K.G. Azithromycin suppresses CD4(+) T-cell activation by direct modulation of mTOR activity. Sci. Rep. 2014, 4, 7438. [PubMed]

95. Goda, J.S.; Le, L.W.; Lapperriere, N.J.; Millar, B.A.; Payne, D.; Gospodarowicz, M.K.; Wells, W.; Hodgson, D.C.; Sun, A.; Simpson, R.; et al. Localized orbital mucosa-assocaited lymphoma tissue lymphoma managed with primary radiation therapy: Efficacy and toxicity. Int. J. Radiat. Oncol. Biol. Phys. 2011, 81, e659-e666. [CrossRef]

96. Hoskin, P.; Popova, B.; Schofield, O.; Brammer, C.; Robinson, M.; Brunt, A.M.; Madhavan, K.; Illidge, T.; Gallop-Evans, E.; Syndikus, I.; et al. 4 Gy versus 24 Gy radiotherapy for follicular and marginal zone lymphoma (FoRT): Long-term follow-up of a multicentre, randomised, phase 3, non-inferiority trial. Lancet Oncol. 2021, 22, 332-340. [PubMed]

97. Ma, W.L.; Yao, M.; Liao, S.L.; Tang, J.L.; Wang, Y.C.; Kuo, S.H.; Cheng, A.L. Chemotherapy alone is an alternative treatment in treating localized primary ocular adnexal lymphomas. Oncotarget 2017, 8, 81329-81342. [CrossRef] [PubMed]

98. Reinartz, G.; Pyra, R.P.; Lenz, G.; Liersch, R.; Stüben, G.; Micke, O.; Willborn, K.; Hess, C.F.; Probst, A.; Fietkau, R.; et al. Favorable radiation field decrease in gastric marginal zone lymphoma: Experience of the German Study Group on Gastrointestinal Lymphoma (DSGL). Strahlenther. Onkol. 2019, 195, 544-557. [PubMed]

99. Yahalom, J.; Xu, A.J.; Noy, A.; Lobaugh, S.; Chelius, M.; Chau, K.; Portlock, C.; Hajj, C.; Imber, B.S.; Straus, D.J.; et al. Involved-site radiotherapy for Helicobacter pylori-independent gastric MALT lymphoma: 26 years of experience with 178 patients. Blood Adv. 2021, 5, 1830-1836. [PubMed]

100. Pinnix, C.C.; Gunther, J.R.; Milgrom, S.A.; Cruz Chamorro, R.J.; Medeiros, L.J.; Khoury, J.D.; Amini, B.; Neelapu, S.; Lee, H.J.; Westin, J.; et al. Outcomes After Reduced-Dose Intensity Modulated Radiation Therapy for Gastric Mucosa-Associated Lymphoid Tissue (MALT) Lymphoma. Int. J. Radiat. Oncol. Biol. Phys. 2019, 104, 447-455. [PubMed]

101. Schmelz, R.; Miehlke, S.; Thiede, C.; Brueckner, S.; Dawel, M.; Kuhn, M.; Ruskoné-Formestraux, A.; Stolte, M.; Jentsch, C.; Hampe, J.; et al. Sequential H. pylori eradication and radiation therapy with reduced dose compared to standard dose for gastric MALT lymphoma stages IE \& II1E: A prospective randomized trial. J. Gastroenterol. 2019, 54, 388-395.

102. Pinnix, C.C.; Dabaja, B.S.; Milgrom, S.A.; Smith, G.L.; Abou, Z.; Nastoupil, L.; Romaguera, J.; Turturro, F.; Fowler, N.; Fayad, L.; et al. Ultra-low-dose radiotherapy for definitive management of ocular adnexal B-cell lymphoma. Head Neck 2017, 39, 1095-1100.

103. Cerrato, M.; Orlandi, E.; Vella, A.; Bartoncini, S.; Iorio, G.C.; Bongiovanni, D.; Capriotti, F.; Boccomini, C.; Vassallo, F.; Cavallin, C.; et al. Efficacy of low-dose radiotherapy $(2 \mathrm{~Gy} \times 2)$ in the treatment of marginal zone and mucosa-associated lymphoid tissue lymphomas. Br. J. Radiol. 2021, 94, 20210012. [PubMed]

104. Baron, J.; Wright, C.M.; Lee, D.Y.; Carpenter, M.; Manjunath, S.H.; Briceño, C.A.; Chong, E.; Maity, A.; Plastaras, J.P.; Paydar, I. Low-Dose Radiotherapy Versus Moderate-Dose Radiotherapy for the Treatment of Indolent Orbital Adnexal Lymphomas. Front. Oncol. 2021, 11, 716002.

105. Kiesewetter, B.; Ferreri, A.J.; Raderer, M. Chemoimmunotherapy for Mucosa-Associated Lymphoid Tissue-Type Lymphoma: A Review of the Literature. Oncologist 2015, 20, 915-925. [PubMed]

106. Cencini, E.; Fabbri, A.; Lauria, F.; Bocchia, M. Long-term efficacy and toxicity of rituximab plus fludarabine and mitoxantrone (R-FM) for gastric marginal zone lymphoma: A single-center experience and literature review. Ann. Hematol. 2018, 97, 821-829. [PubMed]

107. Zucca, E.; Conconi, A.; Martinelli, G.; Bouabdallah, R.; Tucci, A.; Vitolo, U.; Martelli, M.; Pettengell, R.; Salles, G.; Sebban, C.; et al. Final Results of the IELSG-19 Randomized Trial of Mucosa-Associated Lymphoid Tissue Lymphoma: Improved Event-Free and Progression-Free Survival With Rituximab Plus Chlorambucil Versus Either Chlorambucil or Rituximab Monotherapy. J. Clin. Oncol. 2017, 35, 1905-1912.

108. Salar, A.; Domingo-Domenech, E.; Panizo, C.; Nicolas, C.; Bargay, J.; Muntanola, A.; Canales, M.; Bello, J.L.; Sancho, J.M.; Tomas, J.F.; et al. Long-term results of a phase 2 study of rituximab and bendamustine for mucosa-associated lymphoid tissue lymphoma. Blood 2017, 130, 1772-1774. [PubMed]

109. Sindel, A.; Al-Juhaishi, T.; Yazbeck, V. Marginal Zone Lymphoma: State-of-the-Art Treatment. Curr. Treat. Options Oncol. 2019, $20,90$.

110. Denlinger, N.M.; Epperla, N.; William, B.M. Management of relapsed/refractory marginal zone lymphoma: Focus on ibrutinib. Cancer Manag. Res. 2018, 10, 615-624. [CrossRef] [PubMed]

111. Noy, A.; de Vos, S.; Thieblemont, C.; Martin, P.; Flowers, C.R.; Morschhauser, F.; Collins, G.P.; Ma, S.; Coleman, M.; Peles, S.; et al. Targeting Bruton tyrosine kinase with ibrutinib in relapsed/refractory marginal zone lymphoma. Blood 2017, 129, $2224-2232$. 
112. Kiesewetter, B.; Raderer, M. Immunomodulatory treatment for mucosa-associated lymphoid tissue lymphoma (MALT lymphoma). Hematol. Oncol. 2020, 38, 417-424. [PubMed]

113. Govi, S.; Dognini, G.P.; Licata, G.; Crocchiolo, R.; Resti, A.G.; Ponzoni, M.; Ferreri, A.J. Six-month oral clarithromycin regimen is safe and active in extranodal marginal zone B-cell lymphomas: Final results of a single-centre phase II trial. Br. J. Haematol. 2010, 150, 226-229. [CrossRef] [PubMed]

114. Ferreri, A.J.M.; Cecchetti, C.; Kiesewetter, B.; Sassone, M.; Calimeri, T.; Perrone, S.; Ponzoni, M.; Raderer, M. Clarithromycin as a "repurposing drug" against MALT lymphoma. Br. J. Haematol. 2018, 182, 913-915. [CrossRef]

115. Amsden, G.W. Erythromycin, clarithromycin, and azithromycin: Are the differences real? Clin. Ther. 1996, 18, 56-72. [CrossRef]

116. Lagler, H.; Kiesewetter, B.; Dolak, W.; Obermueller, M.; Simonitsch-Klupp, I.; Lukas, J.; Neuper, O.; Lamm, W.W.; Mayerhoefer, M.E.; Raderer, M. Treatment of mucosa associated lymphoid tissue lymphoma with a long-term once-weekly regimen of oral azithromycin: Results from the phase II MALT-A trial. Hematol. Oncol. 2019, 37, 22-26. [CrossRef] [PubMed]

117. Scheibenpflug, R.; Obermüller, M.; Reznicek, G.; Neuper, O.; Lamm, W.W.; Raderer, M.; Lagler, H. Azithromycin concentrations during long-term regimen, a pilot study in patients with MALT lymphoma. Sci. Rep. 2021, 11, 18460.

118. Du, M.-Q. MALT lymphoma: Many roads lead to nuclear factor-kb activation. Histopathology 2011, 58, 26-38. [PubMed]

119. Rodríguez-Sevilla, J.J.; Salar, A. Recent Advances in the Genetic of MALT Lymphomas. Cancers 2021, 14, 176. [PubMed]

120. Yeh, K.H.; Kuo, S.H.; Chen, L.T.; Mao, T.L.; Doong, S.L.; Wu, M.S.; Hsu, H.C.; Tzeng, Y.S.; Chen, C.L.; Lin, J.T.; et al. Nuclear expression of BCL10 or nuclear factor kappa B helps predict Helicobacter pylori-independent status of low-grade gastric mucosa-associated lymphoid tissue lymphomas with or without $t(11 ; 18)(q 21 ; q 21)$. Blood 2005, 106, 1037-1041. [CrossRef] [PubMed]

121. Tsai, H.J.; Tai, J.J.; Chen, L.T.; Wu, M.S.; Yeh, K.H.; Lin, C.W.; Wang, T.E.; Wang, H.P.; Yu, F.J.; Liou, J.M.; et al. Taiwan Cooperative Oncology Group. A multicenter prospective study of first-line antibiotic therapy for early-stage gastric mucosa-associated lymphoid tissue lymphoma and diffuse large B-cell lymphoma with histological evidence of mucosa-associated lymphoid tissue. Haematologica 2020, 105, e349-e354. [PubMed]

122. Hicks, L.K.; Haynes, A.E.; Reece, D.E.; Walker, I.R.; Herst, J.A.; Meyer, R.M.; Imrie, K. Hematology Disease Site Group of the Cancer Care Ontario Program in Evidence-based Care. A meta-analysis and systematic review of thalidomide for patients with previously untreated multiple myeloma. Cancer Treat. Rev. 2008, 34, 442-452. [CrossRef] [PubMed]

123. Gribben, J.G.; Fowler, N.; Morschhauser, F. Mechanisms of Action of Lenalidomide in B-Cell Non-Hodgkin Lymphoma. J. Clin. Oncol. 2015, 33, 2803-2811. [PubMed]

124. Troch, M.; Zielinski, C.; Raderer, M. Absence of efficacy of thalidomide monotherapy in patients with extranodal marginal zone B-cell lymphoma of the mucosa-associated lymphoid tissue (MALT lymphoma). Ann Oncol. 2009, 20, 1446-1447. [CrossRef] [PubMed]

125. Kuo, S.H.; Cheng, A.L.; Lin, C.W.; Hsu, C.H.; Wu, M.S.; Yeh, K.H.; Tzeng, Y.S.; Chen, L.T. t(11;18)(q21;q21) translocation as predictive marker for non-responsiveness to salvage thalidomide therapy in patients with marginal zone B-cell lymphoma with gastric involvement. Cancer Chemother. Pharmacol. 2011, 68, 1387-1395. [CrossRef] [PubMed]

126. Kiesewetter, B.; Troch, M.; Mayerhoefer, M.E.; Dolak, W.; Simonitsch-Klupp, I.; Raderer, M. Delayed Efficacy After Treatment With Lenalidomide or Thalidomide in Patients With Mucosa-Associated Lymphoid Tissue Lymphoma. Oncologist 2016, 21, 72-75. [CrossRef] [PubMed]

127. Kiesewetter, B.; Troch, M.; Dolak, W.; Mullauer, L.; Lukas, J.; Zielinski, C.C.; Raderer, M. A phase II study of lenalidomide in patients with extranodal marginal zone B-cell lymphoma of the mucosa associated lymphoid tissue (MALT lymphoma). Haematologica 2013, 98, 353-356. [CrossRef]

128. Kiesewetter, B.; Lamm, W.; Neuper, O.; Mayerhoefer, M.E.; Simonitsch-Klupp, I.; Raderer, M. Prolonged follow-up on lenalidomide-based treatment for mucosa-associated lymphoid tissue lymphoma (MALT lymphoma)-Real-world data from the Medical University of Vienna. Hematol. Oncol. 2019, 37, 345-351. [PubMed]

129. Nijhof, I.S.; Franssen, L.E.; Levin, M.D.; Bos, G.M.J.; Broijl, A.; Klein, S.K.; Koene, H.R.; Bloem, A.C.; Beeker, A.; Faber, L.M.; et al. Phase $1 / 2$ study of lenalidomide combined with low-dose cyclophosphamide and prednisone in lenalidomide-refractory multiple myeloma. Blood 2016, 128, 2297-2306.

130. Ahlmann, M.; Hempel, G. The effect of cyclophosphamide on the immune system: Implications for clinical cancer therapy. Cancer Chemother. Pharmacol. 2016, 78, 661-671. [PubMed]

131. Madondo, M.T.; Quinn, M.; Plebanski, M. Low dose cyclophosphamide: Mechanisms of T cell modulation. Cancer Treat. Rev. 2016, 42, 3-9. [PubMed]

132. Franssen, L.E.; Nijhof, I.S.; Bjorklund, C.C.; Chiu, H.; Doorn, R.; van Velzen, J.; Emmelot, M.; van Kessel, B.; Levin, M.D.; Bos, G.M.J.; et al. Lenalidomide combined with low-dose cyclophosphamide and prednisone modulates Ikaros and Aiolos in lymphocytes, resulting in immunostimulatory effects in lenalidomide-refractory multiple myeloma patients. Oncotarget 2018, 9 , 34009-34021. [CrossRef] [PubMed]

133. Hussong, J.W.; Perkins, S.L.; Schnitzer, B.; Hargreaves, H.; Frizzera, G. Extramedullary plasmacytoma. A form of marginal zone cell lymphoma? Am. J. Clin. Pathol. 1999, 111, 111-116. [CrossRef] [PubMed]

134. Ruskoné-Fourmestraux, A.; Fischbach, W.; Aleman, B.M.; Boot, H.; Du, M.-Q.; Megraud, F.; Montalban, C.; Raderer, M.; Savio, A.; Wotherspoon, A. EGILS consensus report. Gastric extranodal marginal zone B-cell lymphoma of MALT. Gut 2011, 60, 747-758. [CrossRef] [PubMed] 
135. Coupland, S.E.; Hellmich, M.; Auw-Haedrich, C.; Lee, W.R.; Anagnostopoulos, I.; Stein, H. Plasmacellular differentiation in extranodal marginal zone B cell lymphomas of the ocular adnexa: An analysis of the neoplastic plasma cell phenotype and its prognostic significance in 136 cases. Br. J. Ophthalmol. 2005, 89, 352-359. [CrossRef] [PubMed]

136. Du, M.-Q. MALT lymphoma: Genetic abnormalities, immunological stimulation and molecular mechanism. Best Pract. Res. Clin. Haematol. 2017, 30, 13-23. [PubMed] 